\title{
A multiwell-plate Caenorhabditis elegans assay for assessing the therapeutic potential of Bacteriophages against Clinical Pathogens
}

\section{Prasanth Manohar1,2, Belinda Loh1, Namasivayam Elangovan³, Archana Loganathan ${ }^{4}$, Ramesh Nachimuthu*4, Sebastian Leptihn ${ }^{* 1,5,6}$}

1Zhejiang University-University of Edinburgh (ZJE) Institute, Zhejiang University, School of Medicine, Haining, Zhejiang, PR China

2The Second Affiliated Hospital Zhejiang University (SAHZU), School of Medicine, Hangzhou, Zhejiang, PR China

${ }^{3}$ Department of Biotechnology, School of Bioscience, Periyar University, Salem, Tamil Nadu, India ${ }^{4}$ Antibiotic Resistance and Phage Therapy Lab, Department of Biomedical Science, School of Biosciences and Technology, Vellore, Tamil Nadu, India ${ }^{5}$ Department of Infectious Diseases, Sir Run Run Shaw Hospital, Zhejiang University, School of Medicine, Hangzhou, PR China

6University of Edinburgh Medical School, Biomedical Sciences, College of Medicine \& Veterinary Medicine, The University of Edinburgh, 1 George Square, Edinburgh, EH8 9JZ, United Kingdom

\section{*Corresponding authors:}

\section{Prof. Dr Ramesh Nachimuthu}

Assistant Professor,

School of Biosciences and Technology,

Vellore, Tamil Nadu, India

E-mail: drpnramesh@gmail.com

\section{Prof. Dr Sebastian Leptihn}

Associate Professor,

Zhejiang University-University of Edinburgh (ZJE) Institute,

Zhejiang University, School of Medicine,

Haining, Zhejiang, PR China

E-mail: Leptihn@intl.zju.edu.cn 


\section{Abstract}

In order to establish phage therapy as a standard clinical treatment for bacterial infections, testing of every phage to ensure the suitability and safety of the biological compound is required. While some issues have been addressed over recent years, standard and easy-to-use animal models to test phages are still rare. Testing of phages in highly suitable mammalian models such as mice is subjected to strict ethical regulations, while insect larvae such as the Galleria mellonella model suffers from batch-to-batch variations and requires manual operator skills to inject bacteria, resulting in unreliable experimental outcomes. A much simpler model is the nematode Caenorhabditis elegans which feeds on bacteria, a fast growing and easy to handle organism which can be used in high-throughput screening. In this study, two clinical bacterial strains of Escherichia coli, one Klebsiella pneumoniae and one Enterobacter cloacae strain were tested on the model system together with lytic bacteriophages that we isolated previously. We developed a liquid-based assay, in which the efficiency of phage treatment was evaluated using a scoring system based on microscopy and counting of the nematodes, allowing increasing statistical significance compared to other assays such as larvae or mice. Our work demonstrates the potential to use Caenorhabditis elegans to test the virulence of strains of Klebsiella pneumoniae, Enterobacter cloacae and EHEC/ EPEC as well as the efficacy of bacteriophages to treat or prevent infections, allowing a more reliable evaluation for the clinical therapeutic potential of lytic phages. 
Importance: Validating the efficacy and safety of phages prior to clinical application is crucial to see phage therapy in practice. Current animal models include mice and insect larvae, which pose ethical or technical challenges. This study examined the use of the nematode model organism, $C$. elegans as a quick, reliable and simple alternative for testing phages. The data shows that all the four tested bacteriophages can eliminate bacterial pathogens and protect the nematode from infections. Survival rates of the nematodes increased from $<20 \%$ in the infection group to $>90 \%$ in the phage treatment group. Even the nematodes with poly-microbial infections recovered during phage cocktail treatment. The use of $C$. elegans as a simple whole-animal infection model is a rapid and robust way to study the efficacy of phages before testing them on more complex model animals such as mice.

Keywords: Phage therapy; animal infection model; Caenorhabditis elegans, Phage efficacy; Bacterial pathogens 


\section{Introduction}

Gram-negative bacteria can cause serious infections in humans, including strains from the family of the Enterobacteriaceae (Escherichia coli, Klebsiella pneumoniae and Enterobacter cloacae). Over the years, such pathogenic strains have been exhibiting increasing resistance to last-resort antibiotics such as carbapenems and colistin $(1,2,3)$. With the decreasing number of available antibiotics, global overuse and misuse in both clinical medicine and agriculture, antimicrobial resistance is an undeniable reality which is also unavoidable (4). However, with appropriate governmental regulations concurrent with the education of doctors and patients alike, the velocity at which resistant strains emerge may be decreased. Nonetheless, novel antimicrobial compounds that can be used in medicine and/or agriculture would not only benefit the sectors but are essential for global health. In light of the withdrawal of pharmaceutical global players to discover new classes of small molecule antibiotics, an alternative approach is to use bacteriophages as biological therapeutics $(5,6)$.

Phage therapy is the application of bacterial viruses that kill its host and thus eliminate a bacterial infection. Although phage therapy is an old concept, it is necessary to improve the understanding of antibacterial properties of phages and their applications before bringing phages into clinical practice (7). Bacteriophages are known to be genus-, species-, or even strain-specific and exhibit no or only minimal side effects when infecting pathogens inside a mammalian host $(8,9,10)$. Their interactions within mammalian hosts, in particular with the immune system, are complex and a healthy phageome has been shown to be beneficial to the host $(11,12,13,14)$. In order to translate a phage isolate into a "drug", several challenges need to be addressed, such 
as evaluating host susceptibility to the phage to ensure that the phage can infect and kill the pathogen, genomic analysis to guarantee the absence of virulence factors or lysogeny genes, producing phages at high numbers devoid of any toxic compounds such as bacterial LPS, and testing the efficacy of the phage in an animal model $(15,16)$.

There is a need to improve the current work flow - from its discovery to the application of phages, which includes investigating the efficacy of a phage in a simple animal model $(17,18)$. Many studies have reported the use of waxworms (Galleria mellonella) as a model to study the efficacy of bacteriophages $(15,19,20,21)$. However, it requires a skilful operator to inject bacteria and / or phages into individual larvae which sometimes could result in large variations between batches, and thus lead to nonreproducible observations. While ethical approval is easier to obtain for work with $G$. mellonella, large numbers of larvae are needed to achieve statistical relevance and therefore a considerable amount of time is required to reliably test a phage. While a mammalian host such as mice would be most suitable to test a phage prior to clinical use, ethical approval is difficult to obtain, and experiments take too long (especially for emergency use of phages in compassionate therapy), while low animal numbers also decrease statistical significance. Thus, a robust, reliable and reproducible assay with large numbers of animals would be highly advantageous to test the efficacy of a phage. In this study, we used the nematode Caenorhabditis elegans as a simple whole-animal infection model and established a liquid-based assay in a multi-well format. C. elegans is an established animal infection model to study pathogenesis and to evaluate the efficacy of drugs $(22,23,24,25,26)$. However, and perhaps surprisingly, there are very limited studies that report the use of $C$. elegans as an animal model to evaluate the 
efficacy of phage therapy $(27,28)$. Studies have been conducted to investigate virulence mechanisms of Pseudomonas aeruginosa (29), Burkholderia paseudomallei (30) and Salmonella typhimurium, S. enteritidis and S. pullorum $(31,32,33)$. In addition, infections of C. elegans by pathogenic E. coli, K. pneumoniae, E. cloacae and the Gram-positive Staphylococcus aureus have been studied where the mechanisms of host-pathogen interaction were elucidated, but also the antibacterial activity of phages were examined $(22,27)$. In all of these studies, solid media was used in the experiments, making it a complex, and possibly sub-optimal assay. The goal of our study was to establish a $C$. elegans - pathogen (E. coli, K. pneumoniae and E. cloacae) liquid-based platform to elucidate the efficacy of lytic phages in vivo. Here, we were able to demonstrate that in the presence of lytic phages the lifespan of infected nematodes was increased up to 6fold compared to the controls without phage. In the bacteria infected groups, the nematode survival was reduced by $\sim 80 \%$ within 4 days. Interestingly, the prophylactic treatment (phages introduced one hour before bacterial infection) showed better efficacy than the therapeutic treatment group (phages introduced 2 hours after bacterial infection) across all four tested pathogens. 


\section{Results}

\section{C. elegans as infection models:}

We established a $C$. elegans liquid-based assay with the aim of providing a robust and reliable approach with high numbers of repeats for statistical significance, to study the virulence of bacterial isolates in vivo and the effects of bacteriophages that target these pathogens. Prior to experimental conditions, we conducted a series of control experiments. In our first control, C. elegans were fed with the non-pathogenic E. coli strain OP50 and were observed to live up to 5 days. In the case where no bacteria were added as feed, the lifespan of $C$. elegans was not drastically reduced despite the starvation conditions (S.fig.1).

It had previously been shown that several pathogens have the ability to kill $C$. elegans including Pseudomonas and Klebsiella when the nematodes were exposed to the bacteria in the surrounding media. Thus, nematodes can be used as a model organism to study bacterial infection $(34,35)$. In addition, despite being the bacterium that $C$. elegans can feed on, studies have shown that certain $E$. coli strains which are pathogenic in humans or animals have the ability to infect nematodes as well (36). Therefore, in our second set of control experiments, we sought to determine the pathogenicity of bacterial strains on C. elegans. Groups of 20 nematodes were independently infected with 4 pathogenic strains, Escherichia coli 131, Escherichia coli 311, Klebsiella pneumoniae 235 and Enterobacter cloacae 140 and observed over 5 days. Regardless of strain, when the nematodes were infected with $10^{3} \mathrm{CFU} / \mathrm{mL}$ of bacterial pathogen, they lived beyond five days whereas $10^{7} \mathrm{CFU} / \mathrm{mL}$ caused death within 3 days (S.fig.2). 
As our experimental set-up was conducted in 96-well plates, the maximum volume in each well was $100 \mu \mathrm{L}$. Over extended durations lasting longer than 5 days, the experimental conditions would lead to volume reduction before eventually drying up completely, thus altering the conditions and potentially affecting the results of our study. Therefore, in this study, a bacterial concentration of $10^{5} \mathrm{CFU} / \mathrm{mL}$ was chosen as all nematodes succumbed to infection in less than 5 days.

Nematodes were evaluated based on appearance (reflectance and optical transparency) and mobility (alive: moving; dead: inactive) as observed under an inverted microscope (40x magnification). A representative scoring model is provided in Fig.1. Scoring was performed in 24 hour intervals. We classified phages to be effective if nematode survival was higher than $70 \%$ of the infected nematodes while less than $20 \%$ survival in the infected groups were classified as ineffective.

In order to determine if our model organism is sensitive to endotoxin, four live or heatinactivated pathogenic bacterial strains (E. coli 131, E. coli 311, K. pneumoniae 235 and E. cloacae 140) were tested on the nematodes. When the C. elegans were infected with live pathogenic E. coli, K. pneumoniae or E. cloacae strain, a significant reduction in nematode survival was observed. In contrast, nematode survival was maintained at $95 \%$ when infected with heat-inactivated bacteria indicating that heat stable molecules such as the endotoxin LPS, do not lead to mortality of the worms (S.fig.3). Thus, our experiments show that it is indeed the pathogenicity of the bacteria used in this study that kill the nematode. 
bioRxiv preprint doi: https://doi.org/10.1101/2022.01.05.474866; this version posted January 5, 2022. The copyright holder for this preprint (which was not certified by peer review) is the author/funder, who has granted bioRxiv a license to display the preprint in perpetuity. It is made available under aCC-BY-NC-ND 4.0 International license.

Manohar P. et al. - A liquid C. elegans assay for therapeutic phage testing

\section{Phage therapy enhanced the survival of infected nematodes:}

The first isolate we tested in our study was $E$. coli 131, a clinical strain from a diagnostic centre in Chennai (India), isolated from blood and was previously identified to be enteropathogenic (an EPEC strain) by polymerase chain reaction (PCR) [39, 40]. We established the parameter of $T D_{\text {mean }}$ which we defined as the mean time until we observed the nematodes to die. The TDmean for $E$. coli strain 131-infected worms was found to be 3 days, a significant reduction from the usual lifespan of 5 days (Fig.2A). Escherichia phage myPSH1131 was previously isolated and identified to infect and lyse E. coli strain 131 effectively $[39,40]$. When myPSH1131 was tested alone, no adverse effects on C. elegans were observed (Fig.2A). This shows that the phage preparations were either free of toxic substances that could decrease the $C$. elegans' lifespan or the nematode is not affected by any of the components contained in the solution. In order to study the efficacy of phage treatment, varying ratios of bacteria to phage were tested i.e. $1: 1,1: 10$ and 1:100 which were $10^{5} \mathrm{CFU} / \mathrm{mL}: 10^{5} \mathrm{PFU} / \mathrm{mL}, 10^{5} \mathrm{CFU} / \mathrm{mL}: 10^{6} \mathrm{PFU} /$ $\mathrm{mL}$ and $10^{5} \mathrm{CFU} / \mathrm{mL}: 10^{7} \mathrm{PFU} / \mathrm{mL}$. In the therapeutic treatment group, phage was added after exposure of the nematode to the pathogen. Here, the Escherichia phage myPSH1131 was able to increase survival up to $90 \%$ when bacteria to phage ratio was 1:100 i.e. $10^{5} \mathrm{CFU} / \mathrm{mL}$ against $10^{7} \mathrm{PFU} / \mathrm{mL}$ (Fig.2D). Other ratios tested, i.e: $1: 1$ and 1:10 also showed survival up to 5 days (Fig.2B,C). Similar results were observed for the prophylactic treatment group, with nematode survival up to $90 \%$ after 5 days in 1:100 (Fig.2D). In this group, the phage was added one hour before the pathogen was included into the media. 
Next, we tested the E. coli strain 311 that was isolated from blood and found to be enterohemorrhagic, i.e. an EHEC strain as identified by PCR to classify pathotypes. Here, the $T D_{\text {mean }}$ in infected $C$. elegans was 3 days and no toxicity was observed when the strain specific phage myPSH2311 was used alone (Fig.3A). E. coli strain 311infected nematodes treated with the Escherichia phage, resulted in $90 \%$ survival after 5 days in both therapeutic and prophylactic groups (Fig.3D). At lower phage concentrations however, $1: 1$ and 1:10, the survival was up to $80 \%$ after 4 days (Fig.3B,C).

Next, we tested K. pneumoniae strain 235 , which was isolated from the blood of a patient. Infection with K. pneumoniae 235 was significantly more virulent to C. elegans compared to the two E. coli strains we had tested. The infection killed all the nematodes within 4 days and the TDmean was established to be less than 3 days (Fig.4A). The addition of phage only had no adverse effects on nematode survival. When phages were added to nematodes that had been exposed to K. pneumoniae strain 235 , i.e. the treatment group, nematode survival increased to $80 \%$ irrespective of the phage concentrations that we analysed and the worms stayed alive at 5 days (Fig.4B,C,D). The prophylactic treatment had a slightly increased positive impact on nematode survival when bacteria to phage ratio were 1:100 with $90 \%$ survival after 5 days, compared to the therapeutic group (Fig.4D).

As a fourth pathogenic strain, we tested an Enterobacter cloacae isolate although Enterobacter is known to often be part of the commensal flora in C. elegans (37). However, no Enterobacter species were obtained in our C. elegans when attempting to specifically isolate such species. Similarly to the pathogenic $E$. coli strain 140 compared 
to the E. coli feeding strain OP50, the observations we made illustrates that strains of the same species can exhibit fundamentally different effects on the host, likely due to virulence factors. The E. cloacae strain 140 is a clinical isolate (from a urine sample) obtained from a diagnostic center in Chennai (India) that resulted in mortality of infected nematodes with a TD mean of 3 days (Fig.5A). While purified Enterobacter phage myPSH1140 alone had no negative effect on the nematodes (survival $>90 \%$ ), the therapeutic treatment group showed increased survival to $85 \%$ at 5 days when 1:100 was used (Fig.5D). However both $1: 1$ and $1: 10$ had survival up to $75 \%$ at 5 days (Fig.5B,C). The prophylactic phage treatment allowed survival of $85 \%$ of the nematodes when 1:100 was used but up to $80 \%$ survival at the same time point (Fig.5B,C,D).

Virulence is often assessed with a single pathogen. However, many infections in clinical practice are not caused by a single pathogen but by several, sometimes with opportunistic bacteria complicating the infection. Such poly-microbial infections are rarely investigated in the lab. Here we used a mixture of the pathogens ( $E$. coli 131, $E$. coli 311, K. pneumoniae 235 , E. cloacae) which we had tested individually and investigated them in our animal model. Such poly-microbial infections significantly reduced the survival percentage to $50 \%$ within 2 days, possibly displaying synergistic virulence effects, not cumulative ones as we used the same final number of cells (Fig.6A). When we next investigated if phages had a beneficial effect decreasing mortality of the nematodes, we prepared a so-called "phage cocktail" which contained phages infecting all the pathogens we used in our poly-microbial infection test. When investigating the effect of the phage cocktail alone on the nematodes, no negative influence on survival was observed. Using the mixture of phages in worms exposed to 
the pathogens, the survivability of nematodes was up to $75 \%$ (therapeutic) and $80 \%$ (prophylaxis) when the phage concentration was higher i.e. 1:100 (Fig.6D). A reduction in survival was observed when the phage concentration against bacteria was reduced (Fig.6B,C). This observation demonstrates the efficacy of phage cocktails in reducing the bacterial load caused by the tested poly-microbial infections (Fig.6B,C,D).

As phages can infect and inactivate bacteria in the media surrounding the worm, we next investigated if the phages are being taken up by the nematodes. The amount of phage particles inside the worms was reduced to $10^{2} \mathrm{PFU} / \mathrm{mL}$ from an initial concentration of $10^{6} \mathrm{PFU} / \mathrm{mL}$ after 4 days in a solution containing only the phage (Fig.7). However, a ten-fold higher concentration of phages $\left(\sim 10^{3} \mathrm{PFU} / \mathrm{mL}\right)$ was found in the therapeutic and in the prophylactic treatment groups indicating that phage replication occur inside the nematode (Fig.7).

For all four bacteriophages, the phage treatment resulted in a 6 -fold or higher increase in nematode survival. In all cases, the prophylactic treatment resulted in a higher percentage of nematode survival compared to the therapeutic treatment. This is possibly due to a decrease in bacterial load as phages are able to kill bacteria that are not yet being ingested by the nematode. Regardless of this issue which is not straight forward to test, our work has clearly established that $C$. elegans can serve as a robust and reproducible, statistically valuable testing platform not only for assessing the virulence of bacterial pathogens but more importantly the efficacy of potentially therapeutic phages, a first step towards ensuring safe deployment in phage therapy. 


\section{Discussion}

We have successfully established a liquid-based C. elegans screening platform to investigate the efficacy of potential therapeutic bacteriophages. This robust and reproducible approach to study the antibacterial potential of lytic phages using a wholeanimal infection model is valuable not only because of its ease but also due to better statistics with higher numbers of animals compared to other established assays. We were able to show that our method appears to be employable for a diverse range of pathogens which cause diseases in humans, as they also cause infections in $C$. elegans (38). Most studies involving C. elegans are routinely performed on agar plates. However, the use of a liquid-based screening method has several advantages including time efficiency and easy experimental design, as components can be added to the solution which allows for an even exposure of the nematodes to bacteria and/or bacteriophage. The screening on titer-plates allows quick nematode scoring i.e. makes easy and clear distinguishing of nematodes, as the colorless M9 buffer allows the nematodes to be observed clearly in contrast to solid media. Even though some experience is required to conduct worm survival counts, the skill can be acquired easily. A liquid-based screening with $C$. elegans was previously found to be suitable to address the virulence of Staphylococcus aureus (25). The method employs an approach similar to ours, using C. elegans as a model organism in liquid media requires high-end equipment and the use of bacteriophages has not been established with this method (26). In addition, our assay is easier to use, faster and less cost-intensive. However, in its current form, our assay can be regarded as semi-quantitative as a human operator evaluates the viability of the nematodes. Thus the development of a fully quantitative 
assay would be an improvement for future optimisation of the method. Potential approaches might include a robotic, automated counting of worms using e.g. specifically developed image processing software (39), or an antibody-based ELISA against life/ dead specific marker proteins.

Using the simple animal model in our assay, we have also demonstrated the efficacy of four bacteriophages in increasing the survival of $C$. elegans infected with bacterial pathogens. The four bacteriophages (Escherichia phage myPSH1131, Escherichia phage myPSH2311, Klebsiella phage myPSH1235 and Enterobacter phage myPSH1140) were found to be effective in eliminating the bacterial load, increasing the lifespan of $C$. elegans (Fig.2-5). Although the higher concentration of bacteria-phage ratio (1:100 or $10^{5} \mathrm{CFU} / \mathrm{mL}: 10^{7} \mathrm{PFU} / \mathrm{mL}$ ) showed up to $90 \%$ nematode survival, the lesser concentrations of $1: 1$ and $1: 10$ had at least $80 \%$ survival. Therefore, survivability of the nematodes was observed irrespective of the phage concentration. Also in combination, as a phage cocktail, the phages displayed highly beneficial effects in limiting the impact of poly-microbial infections on the nematodes. To the best of our knowledge, this is the first study to report the successful use of $C$. elegans to test the efficacy of phages in a liquid assay format.

The data from our assay confirms results we have previously obtained in experiments using waxworms (15). In our previous study, when waxworms were infected with bacteria $\left(10^{8} \mathrm{CFU} / \mathrm{mL}\right.$ ) and treated with phages (104 PFU/mL), up to $80 \%$ larval survival was noted (15). In this study, perhaps not surprisingly, the prophylactic treatment allows for better nematode survival rates than the therapeutic treatment where an infection is first established before treating the worm with phages. However, even in the treatment 
regime we obtained statistically significant high survival rates which demonstrate that bacteriophages are able to protect or cure $C$. elegans from bacterial infections caused by the four different clinical strains, also when combined in an effort to reproduce a ploymicrobial infection. We believe that this is the first study to test the pathogenesis of polymicrobial infections in $C$. elegans and also to use phage cocktails against the polymicrobial infections.

As phage therapy becomes an increasingly used clinical intervention to treat MDR infections, the use of simple live animal models in robust and reliable assays like the one we have established for $C$. elegans will facilitate the therapeutic evaluation of phages. While innate immune factors are conserved among nematodes, insects, and mammals, there are distinct differences among lower animals (40 - new reference here: 10.1016/j.molimm.2007.09.030). Both, Galleria and Caenorhabditis lack an adaptive immune system, however studies on the innate immune systems of insects and nematodes have indicated that there are differences in pattern- recognition- molecules and signalling factors. Although results of our work do not indicate any difference (such as a higher/lower tolerance to certain pathogens in $C$. elegans), the insect and the nematode model might show variances when evaluating the virulence of bacteria. However, for clinical phage therapy, in particular for human applications, an animal model with an adaptive immune system should be used. Thus an invertebrate-based screening can only serve as the first stage to evaluate the therapeutic potential of a phage, yet in our case as a rapid and inexpensive one. Such robust, reliable and potentially high-throughput methods can be considered one of the prerequisites for the 
bioRxiv preprint doi: https://doi.org/10.1101/2022.01.05.474866; this version posted January 5, 2022. The copyright holder for this preprint

(which was not certified by peer review) is the author/funder, who has granted bioRxiv a license to display the preprint in perpetuity. It is made available under aCC-BY-NC-ND 4.0 International license.

Manohar P. et al. - A liquid C. elegans assay for therapeutic phage testing

implementation of phage therapy, from the discovery of environmental phages or the construction of synthetic viruses, to the phage solution ready for medical treatment.

\section{Conclusion}

The data provided in this study demonstrates the ability of a liquid-based assay to test the antimicrobial efficacy of bacteriophages to increase the nematode survival when infected with bacterial pathogens. This allows the activity of phages to be tested before large scale pre-clinical studies in mouse models. While the use of $C$. elegans was explored in this study by manual operation, observation and analysis, modifications to our test system could allow the adaptation to establish a high-throughput screening platform for hundreds of bacteriophages in parallel. 


\section{Materials and methods}

\section{Bacterial strains and bacteriophages:}

A total of four clinical bacterial strains, Escherichia coli 131 (Enteropathogenic), Escherichia coli 311 (Enterohemorrhagic), Klebsiella pneumoniae 235 and Enterobacter cloacae 140 were previously studied and chosen for the study $(41,42)$. E. coli pathotypes were identified by polymerase chain reaction as detailed in our previous studies $(41,42)$. Bacterial strains including the non-pathogenic "nematode feeding bacterium" E. coli OP50 were grown on Lysogeny Broth (LB) agar at $37^{\circ} \mathrm{C}$ and stored in LB medium. For the assay, bacterial strains were grown overnight at $37^{\circ} \mathrm{C}$ with shaking at $120 \mathrm{rpm}$, then the culture was diluted to $\mathrm{OD}_{600}=0.6\left(\sim 10^{5} \mathrm{CFU} / \mathrm{mL}\right)$ unless stated otherwise. Heat-inactivated bacteria was prepared by incubating the cells at $65^{\circ} \mathrm{C}$ for 40 $\min$ (43). $1 \mathrm{~mL}$ of cells was pelleted by centrifugation at $4000 \times \mathrm{g}$ for 10 minutes before washing the pellet thrice with PBS and finally resuspending it in $1 \mathrm{~mL}$ PBS. Four bacteriophages, Escherichia phage myPSH1131, Escherichia phage myPSH2311, Klebsiella phage myPSH1235 and Enterobacter phage myPSH1140 were used in this study $(41,42)$. The purified bacteriophages were prepared at $10^{5}-10^{7} \mathrm{PFU} / \mathrm{mL}$ as described previously $(41,42)$. All the bacterial strains and bacteriophages used in this study are available at Antibiotic Resistance and Phage Therapy Laboratory, Vellore Institute of Technology, Vellore, India.

\section{C. elegans maintenance:}

Bristol N2 (wild-type) C. elegans was used in this study and was kindly provided by Dr. N. Elangovan, Periyar University, Salem, India. The nematodes were maintained and propagated on nematode growth media (NGM; $17 \mathrm{~g}$ agar, $3 \mathrm{~g} \mathrm{NaCl}, 2.5 \mathrm{~g}$ peptone, 0.5 
$\mathrm{mL}$ of $1 \mathrm{M} \mathrm{CaCl} 2,1 \mathrm{~mL}$ of $5 \mathrm{mg} / \mathrm{mL}$ cholesterol, $1 \mathrm{~mL}$ of $1 \mathrm{M} \mathrm{MgSO}_{4}, 25 \mathrm{~mL} \mathrm{KH}_{2} \mathrm{PO}_{4}$ buffer [pH 6.0] per litre) plates that carries E. coli OP50 as a source of food at $20^{\circ} \mathrm{C}$ by standard protocols (44). The adult worms were exposed to $5 \mathrm{M}$ sodium hydroxide and $5 \%$ bleach to collect eggs that were then incubated in M9 medium $\left(6 \mathrm{~g} \mathrm{Na}_{2} \mathrm{HPO}_{4}, 3 \mathrm{~g}\right.$ $\left.\mathrm{KH}_{2} \mathrm{PO}_{4}, 5 \mathrm{~g} \mathrm{NaCl}, 0.25 \mathrm{~g} \mathrm{MgSO}_{4} .7 \mathrm{H}_{2} \mathrm{O}\right)$. Worms take approximately 12 hours to hatch, and only mature eggs allow the development of viable nematodes by which synchronization was archived to obtain worms of the same age (45). For the experiments, age synchronized L4 worms were incubated in the presence of tryptic soy broth (TSB), E. coli, K. pneumoniae, E. cloacae and/or bacteriophage of Escherichia phage myPSH1131, Escherichia phage myPSH2311, Klebsiella phage myPSH1235 and Enterobacter phage myPSH1140 in 96 well microtitre plates containing $100 \mu \mathrm{L}$ of M9 buffer in each well.

\section{Testing phage efficacy in C. elegans model:}

Two types of assays were performed i.e. therapeutic treatment and prophylactic treatment. For the liquid-based assay, a 96-well microtiter plate was filled with M9 buffer to which an overnight culture of $E$. coli OP50 (feeding bacteria) or the equivalent amount of pathogenic bacteria, with or without phage was added (Fig.8 ). Then 20 mature L4 nematodes were transferred into the solution. The total volume in the microtiter plate well was maintained at $100 \mu \mathrm{L}$. In order to test the robustness of the experiments, different concentrations of pathogenic bacteria was used to test the infectivity. Accordingly, overnight grown bacterial cultures were diluted to $10^{3}, 10^{5}$ and $10^{7} \mathrm{CFU} / \mathrm{mL}$ for testing. The efficacy of phage treatment was studied using varying 
concentrations of bacteria and phage i.e. $1: 1,1: 10$ and $1: 100$ which were $10^{5} \mathrm{CFU} / \mathrm{mL}$ : $10^{5} \mathrm{PFU} / \mathrm{mL}$ and $10^{5} \mathrm{CFU} / \mathrm{mL}: 10^{6} \mathrm{PFU} / \mathrm{mL}$ and $10^{5} \mathrm{CFU} / \mathrm{mL}: 10^{7} \mathrm{PFU} / \mathrm{mL}$.

Group 1 (control) consisted of M9 buffer (60\%) with E. coli OP50, with $\sim 10^{5} \mathrm{CFU} / \mathrm{mL}$ (40\%) and 20 nematodes. Group 2 M9 buffer, 20 nematodes, no bacteria. Group 3 M9 buffer $(60 \%)$, TSB $(40 \%), 20$ nematodes. Both groups 2 and 3 were used as experimental controls. Group 4 (infection control): M9 buffer (60\%), bacterial pathogen (E. coli or K. pneumoniae or E. cloacae, 40\%), 20 nematodes. Group 5 (heat inactivated bacteria): M9 buffer $(60 \%)$, heat-inactivated bacteria ( $E$. coli or $K$. pneumoniae or E. cloacae, 40\%), 20 nematodes. Group 6 (phage toxicity test): M9 buffer (60\%), bacteriophage (Escherichia phage myPSH1131, Escherichia phage myPSH2311, Klebsiella phage myPSH1235 and Enterobacter phage myPSH1140, 40\%) and 20 nematodes. Group 7 (therapeutic treatment group): M9 buffer (40\%), bacterial pathogen (E. coli or K. pneumoniae or E. cloacae, 30\%), 20 nematodes; bacteriophage (30\%) were added after 2 hours of exposure to bacteria. Group 8 (prophylactic treatment group): M9 buffer (40\%), bacteriophage (30\%), 20 nematodes; bacterial cultures of $E$. coli or K. pneumoniae or E. cloacae (30\%) were added after 1 hour. Plates were incubated at $20^{\circ} \mathrm{C}$ and survival of the nematodes was monitored every 24 hours for 5 days. The results were evaluated based on live nematodes (moving) and dead nematodes (lack of movement), see Fig.1. The L4 stage nematodes were chosen for the study because even though the lifespan of $C$. elegans is $20 \pm 3$ days, nematodes drastically reduce motility when ageing, making it difficult to establish if infected (46). All the experiments were repeated a minimum of three times for statistical significance. 
The efficacy of a phage cocktail was evaluated by establishing poly-microbial infections. To this end, the bacterial cultures were mixed at equal volumes containing the same CFU numbers. Heat-inactivated bacteria were also prepared from the mixed culture. The phage cocktail was prepared by mixing the bacteriophages at equal volumes with identical PFUs. The efficacy of phage treatment was studied using varying concentrations of bacteria and phage i.e. $1: 1,1: 10$ and $1: 100$ which were $10^{5} \mathrm{CFU} / \mathrm{mL}$ : $10^{5} \mathrm{PFU} / \mathrm{mL}, 10^{5} \mathrm{CFU} / \mathrm{mL}: 10^{6} \mathrm{PFU} / \mathrm{mL}$ and $10^{5} \mathrm{CFU} / \mathrm{mL}: 10^{7} \mathrm{PFU} / \mathrm{mL}$. Group 1 consisted of M9 buffer (60\%) with E. coli OP50 (40\%) and 20 nematodes. Group 2 M9 buffer, 20 nematodes, no bacteria. Group 3 M9 buffer (60\%), TSB (40\%), 20 nematodes. Group 4 (infection control): M9 buffer (60\%), mixed bacterial culture (E. coli, K. pneumoniae, E. cloacae, 40\%), 20 nematodes. Group 5 (heat inactivated bacteria): M9 buffer (60\%), heat-killed bacteria (poly-microbial), 20 nematodes. Group 6 (phage toxicity test): M9 buffer $(60 \%)$, phage cocktail (consists of four phages, $40 \%$ ) and 20 nematodes. Group 7 (therapeutic treatment group): M9 buffer (40\%), mixed bacterial culture (E. coli, K. pneumoniae, E. cloacae, 40\%), 20 nematodes; phage cocktail (30\%) was added after 2 hours of exposure to the bacteria. Group 8 (prophylactic treatment group): M9 buffer (40\%), phage cocktail (30\%), 20 nematodes; the poly-microbial culture containing E. coli, K. pneumoniae, E. cloacae (30\%) was added after 1 hour. Plates were incubated at $20^{\circ} \mathrm{C}$ and survival of the nematodes was monitored every 24 hours for 5 days. The results were evaluated and statistical analysis was performed.

\section{Enumeration of bacteriophages from the treated nematodes:}


To analyse the presence of bacteriophages inside the nematodes or uptake of bacteriophages by the nematodes, phages numbers were determined as follows: Briefly, after 4 days, 10 nematodes were removed from groups 5,6 and 7 which are phage only, therapeutic treatment and prophylactic treatment, respectively, to determine the phage titer using double agar overlay method. In brief, the nematodes were washed thrice with M9 buffer, vortexed, ground (with mortar and pestle) and centrifuged at $10,000 \times \mathrm{g}$ for $5 \mathrm{~min}$. The supernatant was used to determine the phage titer. All bacteriophages were used alone (not in combination) and the experiments were repeated three times for statistical significance.

\section{Statistical analysis:}

Survival curves were plotted using Kaplan-Meier method and log-rank test was used to calculate the difference in survival rates using GraphPad Prism software 7.0 (GraphPad Software, Inc., La Jolla, USA). P $<0.05$ was considered as statistically significant (logrank test).

\section{Acknowledgement}

The authors would like to thank Vellore Institute of Technology for providing 'VIT Seed Grant' and the support provided by the Zhejiang Province Postdoctoral Research Fund (ZJ2020151) to Prasanth Manohar. The authors gratefully acknowledge Caenorhabditis Genetic Centre (CGC, University of Minnesota, MN, USA) which is funded by NIH Office of Research Infrastructure Programs (P40 OD010440) for providing Bristol N2 (wild type) used in this work. 
bioRxiv preprint doi: https://doi.org/10.1101/2022.01.05.474866; this version posted January 5, 2022. The copyright holder for this preprint (which was not certified by peer review) is the author/funder, who has granted bioRxiv a license to display the preprint in perpetuity. It is made available under aCC-BY-NC-ND 4.0 International license.

Manohar P. et al. - A liquid C. elegans assay for therapeutic phage testing

\section{References:}

1. Manohar P, Leptihn S, Lopes BS, Nachimuthu R. Dissemination of carbapenem resistance and plasmids encoding carbapenemases in Gram-negative bacteria isolated in India, JACAntimicrobial Resistance, 3(1), 2021, dlab015, https://doi.org/10.1093/jacamr/dlab015

2. Reardon S. Resistance to last-ditch antibiotic has spread farther than anticipated. Nature. 2017 Jun $12 ; 10$.

3. Wang Q, Wang P, Yang Q. Occurrence and diversity of antibiotic resistance in untreated hospital wastewater. Science of the Total Environment. 2018 Apr 15;621:990-9.

4. Leptihn S. Welcome back to the pre-penicillin era. why we desperately need new strategies in the battle against bacterial pathogens. Infect. Microbes Dis. 2019 Nov 8;1(33):10-97.

5. Pires DP, Costa AR, Pinto G, Meneses L, Azeredo J. Current challenges and future opportunities of phage therapy. FEMS Microbiology Reviews. 2020 Nov;44(6):684-700.

6. Loh B, Leptihn S. A call for a multidisciplinary future of Phage Therapy to combat multi-drug resistant bacterial infections. Infectious Microbes \& Diseases. 2020 2(1): 1-2.

7. Pirnay JP. Phage therapy in the year 2035. Frontiers in Microbiology. 2020 Jun 3;11:1171.

8. Nale JY, Clokie MR. Preclinical data and safety assessment of phage therapy in humans. Current Opinion in Biotechnology. 2021 Apr 1;68:310-7.

9. Petrovic Fabijan A, Khalid A, Maddocks S, Ho J, Gilbey T, Sandaradura I, Lin RC, Ben Zakour N, Venturini C, Bowring B, Iredell JR. Phage therapy for severe bacterial infections: a narrative review. Medical Journal of Australia. 2020 Apr;212(6):279-85.

10. Gordillo Altamirano FL, Barr JJ. Phage therapy in the postantibiotic era. Clinical microbiology reviews. 2019;32(2):e00066-18.

11. Manohar P, Ramesh N, Leptihn S, Ravi A, Rudi K. Reduced metagenomic sequencing (RMS) approach to determine the gut-associated phageome in mother-child. Human Microbiome Journal. 2021 Mar 1;19:100078.

12. Manohar P, Tamhankar AJ, Leptihn S, Ramesh N. Pharmacological and immunological aspects of phage therapy. Infectious Microbes \& Diseases. 2019 Dec 1;1(2):34-42.

13. Townsend EM, Kelly L, Muscatt G, Box JD, Hargraves N, Lilley D, Jameson E. The Human Gut Phageome: Origins and Roles in the Human Gut Microbiome. Frontiers in Cellular and Infection Microbiology. 2021 Jun 4;11:498.

14. Dąbrowska K, Abedon ST. Pharmacologically aware phage therapy: pharmacodynamic and pharmacokinetic obstacles to phage antibacterial action in animal and human bodies. Microbiology and Molecular Biology Reviews. 2019 Oct 30;83(4):e00012-19.

15. Manohar P, Nachimuthu R, Lopes BS. The therapeutic potential of bacteriophages targeting gram-negative bacteria using Galleria mellonella infection model. BMC microbiology. 2018 Dec;18(1):1-1.

16. Brix A, Cafora $M$, Aureli $M$, Pistocchi A. Animal models to translate phage therapy to human medicine. International Journal of Molecular Sciences. 2020 Jan;21(10):3715.

17. Melo LD, Oliveira H, Pires DP, Dabrowska K, Azeredo J. Phage therapy efficacy: a review of the last 10 years of preclinical studies. Critical reviews in microbiology. 2020 Jan 2;46(1):78-99.

18. Schooley RT, Biswas B, Gill JJ, Hernandez-Morales A, Lancaster J, Lessor L, Barr JJ, Reed SL, Rohwer F, Benler S, Segall AM. Development and use of personalized bacteriophage-based therapeutic cocktails to treat a patient with a disseminated resistant Acinetobacter baumannii infection. Antimicrobial agents and chemotherapy. 2017 Oct 1;61(10).

19. Jeon J, Park JH, Yong D. Efficacy of bacteriophage treatment against carbapenem-resistant Acinetobacter baumannii in Galleria mellonella larvae and a mouse model of acute pneumonia. BMC microbiology. 2019 Dec;19(1):1-4.

20. Antoine C, Laforêt F, Blasdel B, Glonti T, Kutter E, Pirnay JP, Mainil J, Delcenserie V, Thiry D. Efficacy assessment of PEV2 phage on Galleria mellonella larvae infected with a Pseudomonas aeruginosa dog otitis isolate. Research in Veterinary Science. 2021 May 1;136:598-601.

21. Jeon J, Yong D. Two novel bacteriophages improve survival in Galleria mellonella infection and mouse acute pneumonia models infected with extensively drug-resistant Pseudomonas aeruginosa. Applied and environmental microbiology. 2019 May 1;85(9):e02900-18.

22. Balla KM, Troemel ER. Caenorhabditis elegans as a model for intracellular pathogen infection. Cellular microbiology. 2013 Aug;15(8):1313-22. 
bioRxiv preprint doi: https://doi.org/10.1101/2022.01.05.474866; this version posted January 5, 2022. The copyright holder for this preprint (which was not certified by peer review) is the author/funder, who has granted bioRxiv a license to display the preprint in perpetuity. It is made available under aCC-BY-NC-ND 4.0 International license.

Manohar P. et al. - A liquid C. elegans assay for therapeutic phage testing

23. Moy TI, Ball AR, Anklesaria Z, Casadei G, Lewis K, Ausubel FM. Identification of novel antimicrobials using a live-animal infection model. Proceedings of the National Academy of Sciences. 2006 Jul 5;103(27):10414-9.

24. Marsh EK, May RC. Caenorhabditis elegans, a model organism for investigating immunity. Applied and environmental microbiology. 2012 Apr 1;78(7):2075-81.

25. Kong C, Yehye WA, Abd Rahman N, Tan MW, Nathan S. Discovery of potential anti-infectives against Staphylococcus aureus using a Caenorhabditis elegans infection model. BMC complementary and alternative medicine. 2014 Dec;14(1):1-7.

26. Anderson QL, Revtovich AV, Kirienko NV. A High-throughput, High-content, Liquid-based C. elegans Pathosystem. Journal of visualized experiments: JoVE. 2018(137).

27. Głowacka-Rutkowska A, Gozdek A, Empel J, Gawor J, Żuchniewicz K, Kozińska A, Dębski J, Gromadka R, Łobocka M. The ability of lytic staphylococcal podovirus vB_SauP_phiAGO1. 3 to coexist in equilibrium with its host facilitates the selection of host mutants of attenuated virulence but does not preclude the phage antistaphylococcal activity in a nematode infection model. Frontiers in microbiology. 2019 Jan 18;9:3227.

28. Santander J, Robeson J. Bacteriophage prophylaxis against Salmonella enteritidis and Salmonella pullorum using Caenorhabditis elegans as an assay system. Electronic Journal of biotechnology. 2004 Aug;7(2):206-9.

29. Gallagher LA, Manoil C. Pseudomonas aeruginosa PAO1 kills Caenorhabditis elegans by cyanide poisoning. Journal of bacteriology. 2001 Nov 1;183(21):6207-14.

30. O'quinn AL, Wiegand EM, Jeddeloh JA. Burkholderia pseudomallei kills the nematode Caenorhabditis elegans using an endotoxin-mediated paralysis. Cellular microbiology. 2001 Jun;3(6):381-93.

31. Aballay A, Yorgey P, Ausubel FM. Salmonella typhimurium proliferates and establishes a persistent infection in the intestine of Caenorhabditis elegans. Current Biology. 2000 Nov 1;10(23):1539-42.

32. Aballay A, Ausubel FM. Programmed cell death mediated by ced-3 and ced-4 protects Caenorhabditis elegans from Salmonella typhimurium-mediated killing. Proceedings of the National Academy of Sciences. 2001 Feb 27;98(5):2735-9.

33. Santander J, Robeson J. Bacteriophage prophylaxis against Salmonella enteritidis and Salmonella pullorum using Caenorhabditis elegans as an assay system. Electronic Journal of biotechnology. 2004 Aug;7(2):206-9.

34. Cohen LB, Troemel ER. Microbial pathogenesis and host defense in the nematode C. elegans. Current opinion in microbiology. 2015 Feb 1;23:94-101.

35. Kamaladevi A, Balamurugan K. Response of Caenorhabditis elegans during Klebsiella pneumoniae pathogenesis. BMC Infectious Diseases. 2014 May;14(3):1-.

36. Schifano E, Marazzato M, Ammendolia MG, Zanni E, Ricci M, Comanducci A, Goldoni P, Conte MP, Uccelletti D, Longhi C. Virulence behavior of uropathogenic Escherichia coli strains in the host model Caenorhabditis elegans. MicrobiologyOpen. 2019 Jun;8(6):e00756.

37. Berg M, Zhou XY, Shapira M. Host-specific functional significance of Caenorhabditis gut commensals. Frontiers in microbiology. 2016 Oct 17;7:1622.

38. Couillault $C$, Ewbank JJ. Diverse bacteria are pathogens of Caenorhabditis elegans. Infection and immunity. 2002 Aug 1;70(8):4705-7.

39. Ljosa V, Sokolnicki KL, Carpenter AE. Annotated high-throughput microscopy image sets for validation. Nature methods. 2012 Jun 28;9(7):637-.

40. Radeke LJ, Herman MA. Take a Walk to the Wild Side of Caenorhabditis elegans-Pathogen Interactions. Microbiology and Molecular Biology Reviews. 2021 Mar 17;85(2):e00146-20.

41. Manohar P, Tamhankar AJ, Lundborg CS, Nachimuthu R. Therapeutic characterization and efficacy of bacteriophage cocktails infecting Escherichia coli, Klebsiella pneumoniae, and Enterobacter species. Frontiers in microbiology. 2019 Mar 21;10:574.

42. Manohar P, Tamhankar AJ, Lundborg CS, Ramesh N. Isolation, characterization and in vivo efficacy of Escherichia phage myPSH1131. PloS one. 2018 Oct 24;13(10):e0206278.

43. Anderson A, McMullan R. Neuronal and non-neuronal signals regulate Caernorhabditis elegans avoidance of contaminated food. Philosophical Transactions of the Royal Society B: Biological Sciences. 2018 Jul 19;373(1751):20170255

44. Brenner S. The genetics of Caenorhabditis elegans. Genetics. 1974 May 1;77(1):71-94.

45. Fabian TJ, Johnson TE. Production of age-synchronous mass cultures of Caenorhabditis elegans. Journal of gerontology. 1994 Jul 1;49(4):B145-56. 
bioRxiv preprint doi: https://doi.org/10.1101/2022.01.05.474866; this version posted January 5, 2022. The copyright holder for this preprint

(which was not certified by peer review) is the author/funder, who has granted bioRxiv a license to display the preprint in perpetuity. It is made available under aCC-BY-NC-ND 4.0 International license.

Manohar P. et al. - A liquid C. elegans assay for therapeutic phage testing

46. Puchalt JC, Sánchez-Salmerón AJ, Ivorra E, Martínez SG, Martínez R, Guerola PM. Improving lifespan automation for Caenorhabditis elegans by using image processing and a post-processing adaptive data filter. Scientific Reports. 2020 May 26;10(1):1-4. 
Figures:

Figure 1

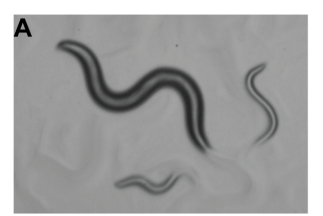

Harvest L4 stage

C. elegans

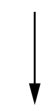

Add to multiwell plate (20 nematodes / well)

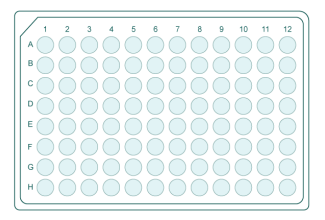

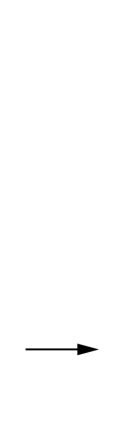
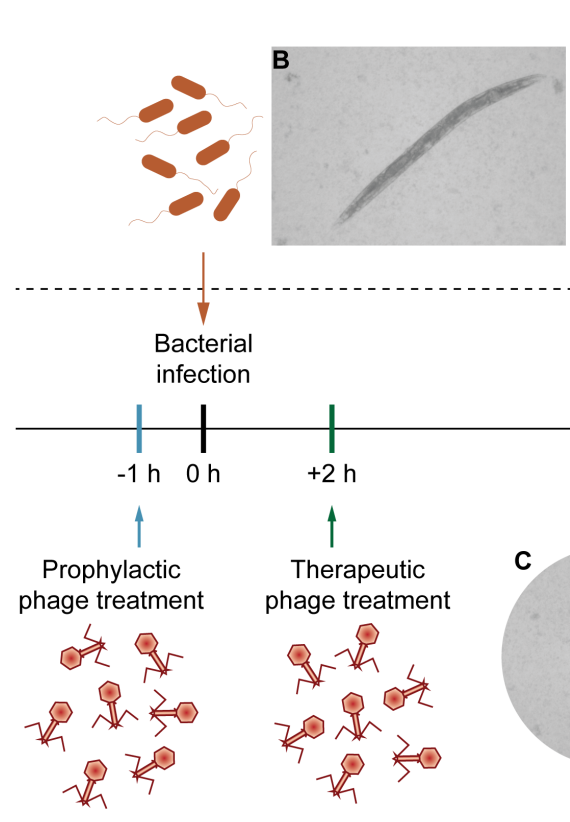

\section{al}
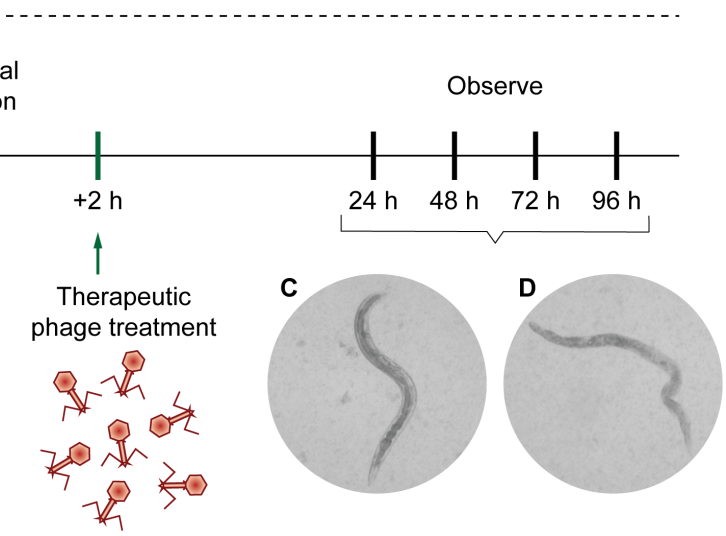

\section{Figure 1:}

Schematic representation of the assay and distinct appearances of the nematode $C$. elegans on solid or in liquid medium. Representative microscopic images may serve as a guide for scoring by the operator. Movement is an important indicator for the viability of a worm but not a strict requirement to score a nematode to be alive. (A) C. elegans on NGA plates, $(B, C)$ Live L4 stage mature nematodes in liquid medium. (D) Dead nematode after bacterial infection. The worms were examined under an inverted microscope at $40 x$ magnification. 


\section{Figure 2}

A

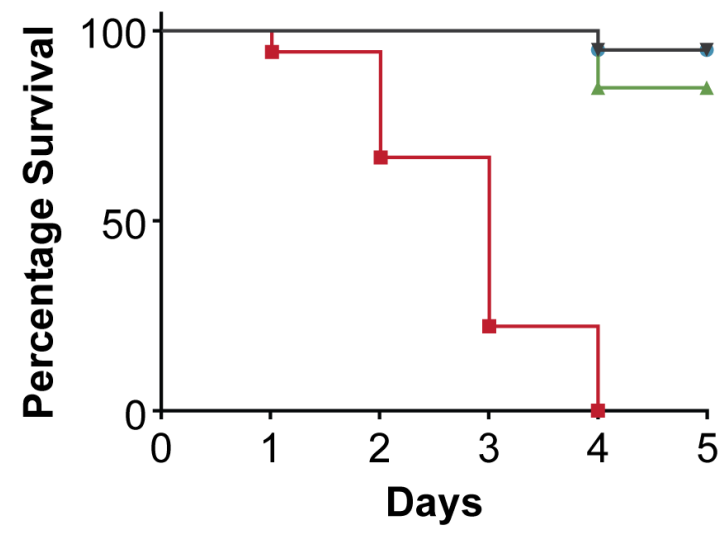

C

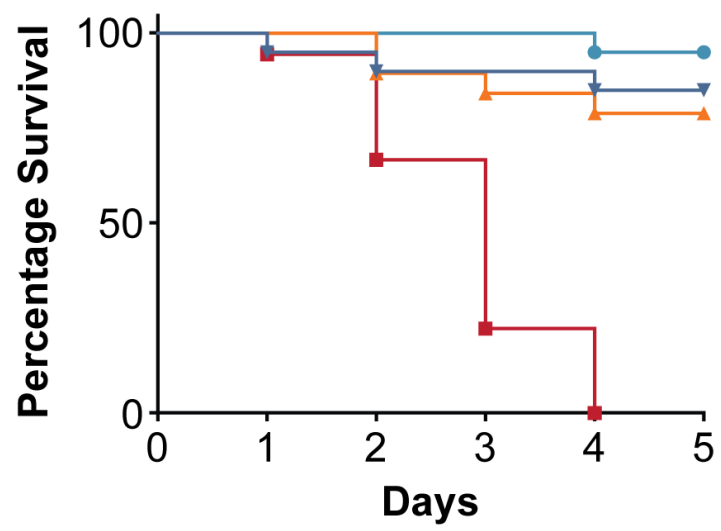

B

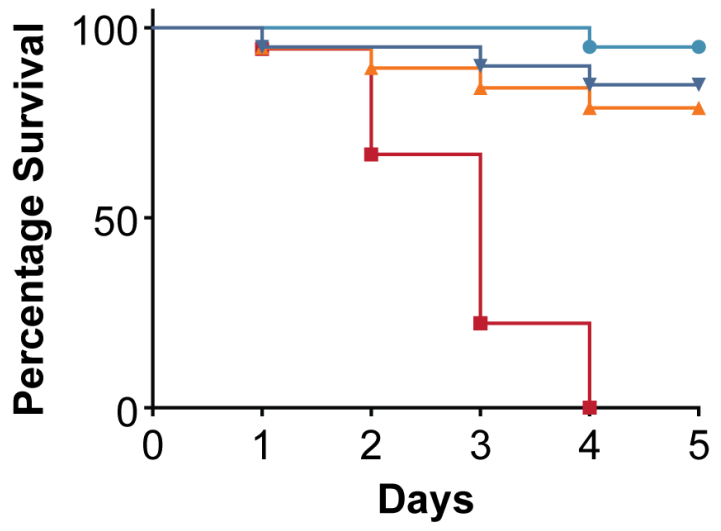

D

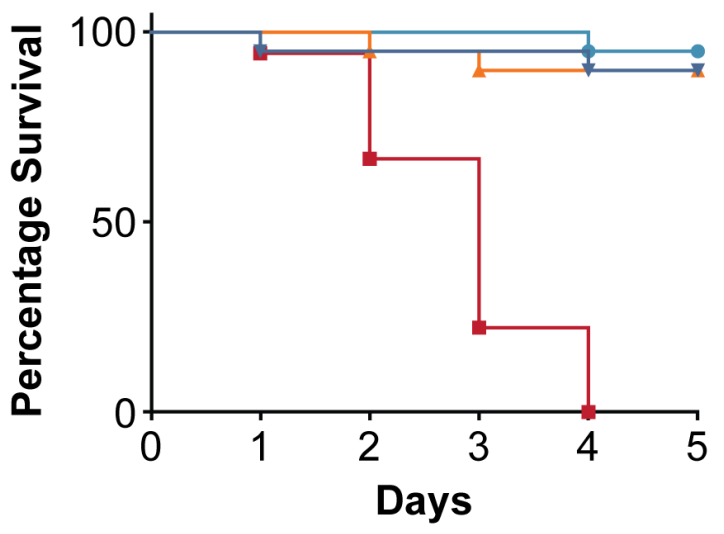

$\rightarrow$ Control $\rightarrow$ Bacteria $\rightarrow$ Phage $\rightarrow$ Heat-inactivated $\rightarrow$ Therapeutic $\rightarrow$ Prophylaxis

Figure 2: Pathogenicity of Escherichia coli strain 131 in C. elegans and efficacy of Escherichia phage myPSH1131 against $E$. coli infections. The control group consisted of $C$. elegans fed with $E$. coli OP50 and exposed to $E$. coli strain 131 $\left(\mathrm{OD}_{600}=0.6\right)$ that kills $C$. elegans in liquid medium. 20 nematodes were used in each group. Representative survival curves of $C$. elegans following infection by $E$. coli strain 131 in (A) liquid medium consisting of M9 buffer and E. coli culture or Escherichia phage or heat-inactivated bacteria and $(\mathbf{B}, \mathbf{C}, \mathbf{D})$ survival curves of $C$. elegans following infection with $E$. coli strain 131 and treatment with Escherichia phage, therapeutic and prophylactic treatment. (B) Survival curves of $C$. elegans infected and treated with bacteria and phage ratio of $1: 1$ i.e. $10^{5} \mathrm{CFU} / \mathrm{mL}$ and $10^{5} \mathrm{PFU} / \mathrm{mL}$, (C) Survival curves of C. elegans infected and treated with bacteria and phage ratio of 1:10 i.e. $10^{5} \mathrm{CFU} / \mathrm{mL}$ and $10^{6} \mathrm{PFU} / \mathrm{mL}$, (D) Survival curves of $C$. elegans infected and treated with bacteria and phage ratio of 1:100 i.e. $10^{5} \mathrm{CFU} / \mathrm{mL}$ and $10^{7} \mathrm{PFU} / \mathrm{mL}$. The survival curves were plotted using Kaplan-Meier method and log-rank test was used to analyze the difference in survival rates in GraphPad Prism 7.0. A statistically significant difference $(p<0.05)$ was observed in the treatment groups. 
Figure 3

A

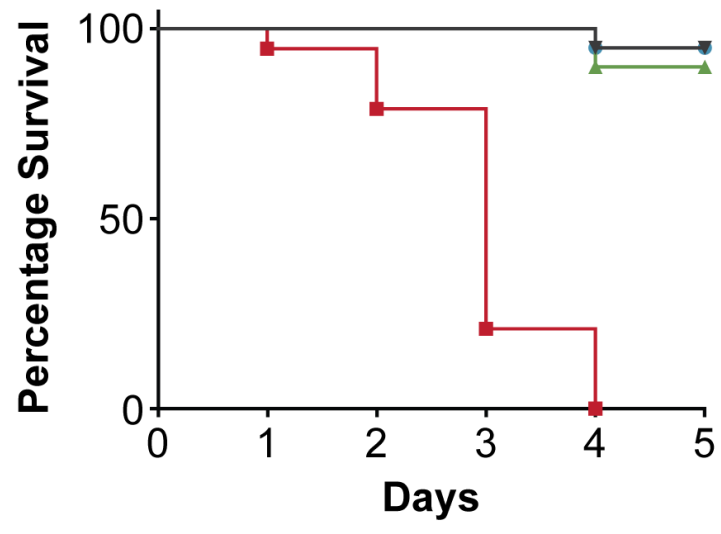

C

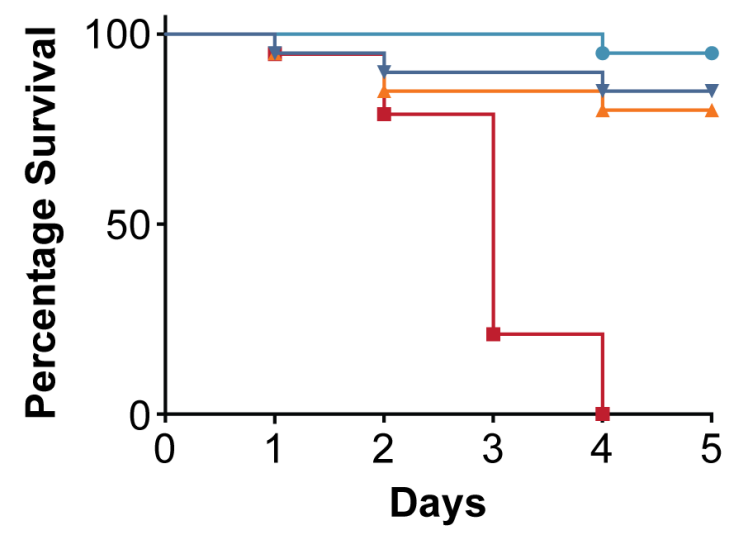

B

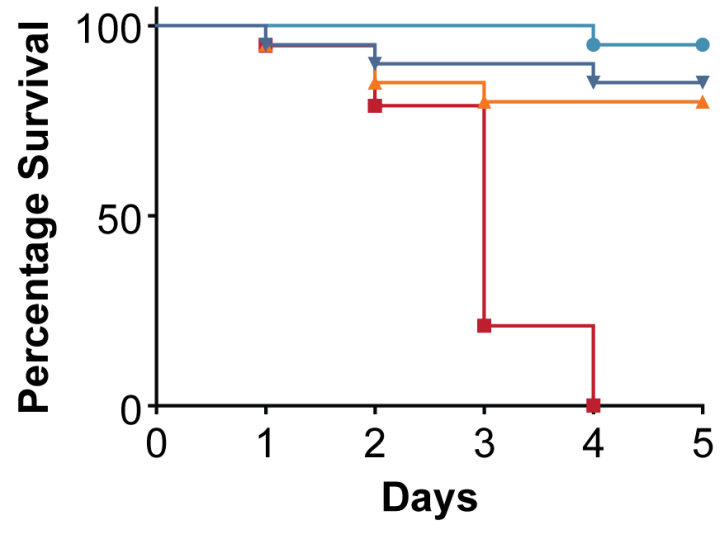

D

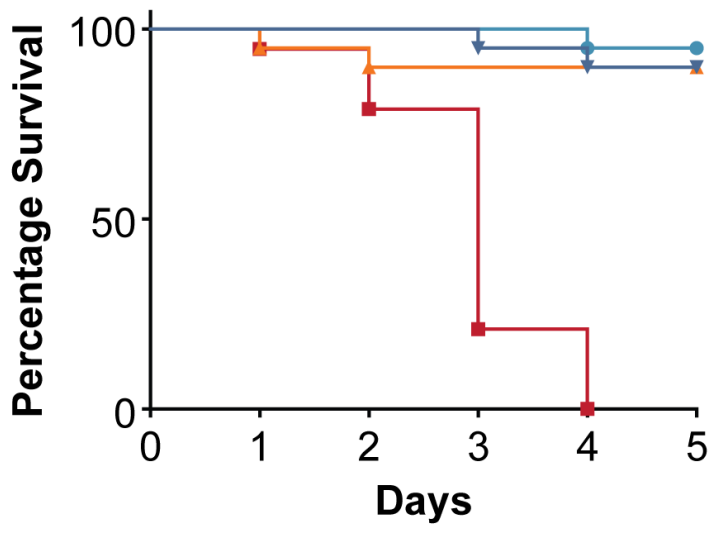

$\rightarrow$ Control $\rightarrow$ Bacteria $\rightarrow$ Phage $\rightarrow$ Heat-inactivated $\rightarrow$ Therapeutic $\rightarrow$ Prophylaxis

Figure 3: Pathogenicity of Escherichia coli strain 311 in C. elegans and efficacy of Escherichia phage myPSH2311 against $E$. coli infections. The control group consisted of $C$. elegans feed with $E$. coli OP50 and E. coli strain $311\left(\mathrm{OD}_{600}=0.6\right)$ that kills C. elegans in liquid medium. 20 nematodes were used in each group. Representative survival curves of $C$. elegans following infection by $E$. coli strain 311 in (A) liquid medium consisting of M9 buffer and E. coli culture or Escherichia phage or heat-inactivated bacteria and $(B, C, D)$ survival curves of $C$. elegans following infection with E. coli strain 311 and treatment with Escherichia phage, therapeutic and prophylactic treatment. (B) Survival curves of $C$. elegans infected and treated with bacteria and phage ratio of $1: 1$ i.e. $10^{5} \mathrm{CFU} / \mathrm{mL}$ and $10^{5} \mathrm{PFU} / \mathrm{mL}$, (C) Survival curves of C. elegans infected and treated with bacteria and phage ratio of 1:10 i.e. $10^{5} \mathrm{CFU} / \mathrm{mL}$ and $10^{6} \mathrm{PFU} / \mathrm{mL}$, (D) Survival curves of $C$. elegans infected and treated with bacteria and phage ratio of 1:100 i.e. $10^{5} \mathrm{CFU} / \mathrm{mL}$ and $10^{7} \mathrm{PFU} / \mathrm{mL}$, The survival curves were plotted using Kaplan-Meier method and log-rank test was used to analyze the difference 
bioRxiv preprint doi: https://doi.org/10.1101/2022.01.05.474866; this version posted January 5, 2022. The copyright holder for this preprint

(which was not certified by peer review) is the author/funder, who has granted bioRxiv a license to display the preprint in perpetuity. It is made available under aCC-BY-NC-ND 4.0 International license.

Manohar P. et al. - A liquid C. elegans assay for therapeutic phage testing

in survival rates in GraphPad Prism 7.0. A statistically significant difference $(p<0.05)$ was observed in the treatment groups. 
Figure 4

A

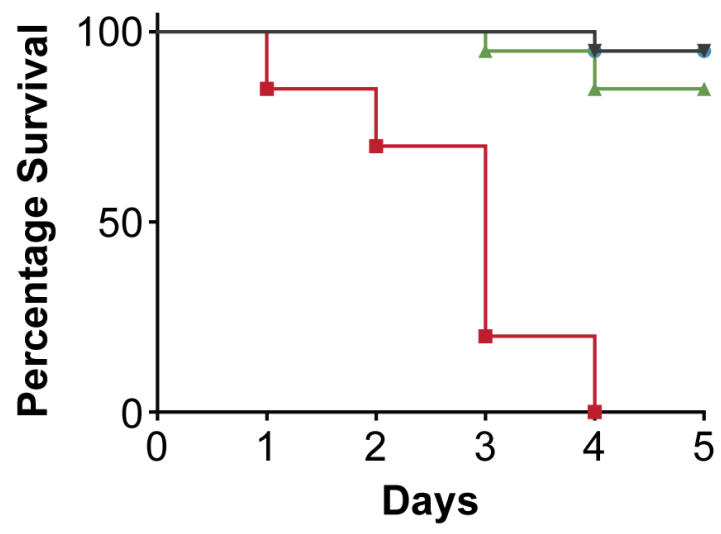

C

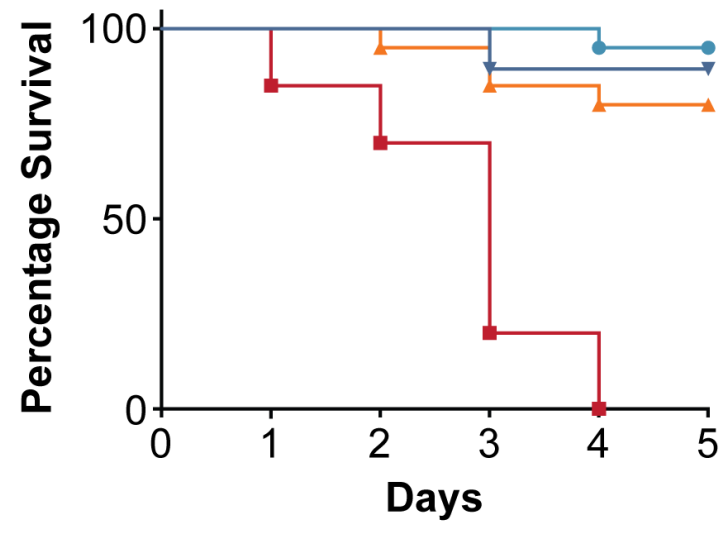

B

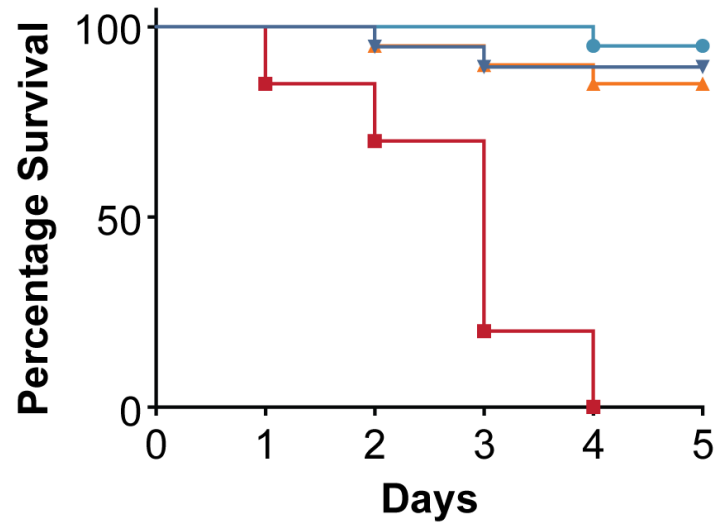

D

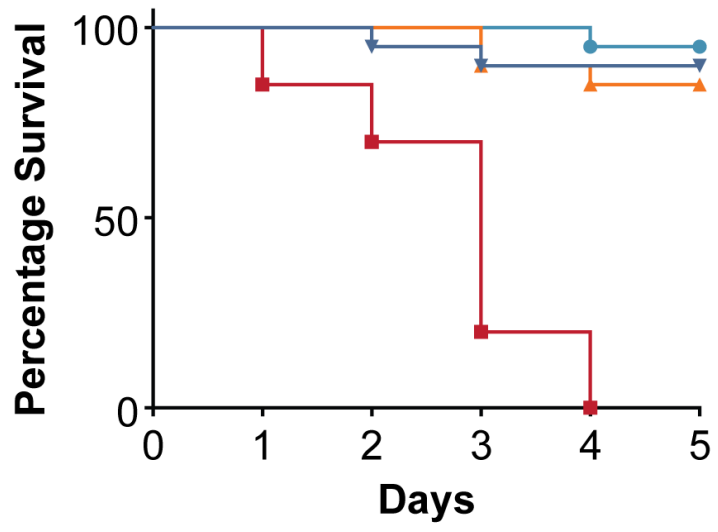

$\rightarrow$ Control $\rightarrow$ Bacteria $\rightarrow$ Phage $\rightarrow$ Heat-inactivated $\rightarrow$ Therapeutic $\rightarrow$ Prophylaxis

Figure 4: Pathogenicity of Klebsiella pneumoniae strain 235 in C. elegans and efficacy of Klebsiella phage myPSH1235 against $K$. pneumoniae infections. The control group consisted of $C$. elegans fed with $E$. coli OP50 and exposed to $K$. pneumoniae strain $235\left(\mathrm{OD}_{600}=0.6\right)$ kills $C$. elegans in liquid medium. 20 nematodes were used in each group. Representative survival curves of $C$. elegans following infection by K. pneumoniae strain 235 in (A) liquid medium consisting of M9 buffer and $K$. pneumoniae culture or Klebsiella phage or heat-inactivated bacteria and $(\mathbf{B}, \mathbf{C}, \mathbf{D})$ survival curves of $C$. elegans following infection with $K$. pneumoniae strain 235 and treatment with Klebsiella phage, therapeutic and prophylactic treatment. (B) Survival curves of $C$. elegans infected and treated with bacteria and phage ratio of 1:1 i.e. $10^{5}$ $\mathrm{CFU} / \mathrm{mL}$ and $10^{5} \mathrm{PFU} / \mathrm{mL}$, (C) Survival curves of C. elegans infected and treated with bacteria and phage ratio of $1: 10$ i.e. $10^{5} \mathrm{CFU} / \mathrm{mL}$ and $10^{6} \mathrm{PFU} / \mathrm{mL}$, (D) Survival curves of $C$. elegans infected and treated with bacteria and phage ratio of 1:100 i.e. $10^{5} \mathrm{CFU} /$ $\mathrm{mL}$ and $10^{7} \mathrm{PFU} / \mathrm{mL}$. The survival curves were plotted using Kaplan-Meier method and 
bioRxiv preprint doi: https://doi.org/10.1101/2022.01.05.474866; this version posted January 5, 2022. The copyright holder for this preprint (which was not certified by peer review) is the author/funder, who has granted bioRxiv a license to display the preprint in perpetuity. It is made available under aCC-BY-NC-ND 4.0 International license.

Manohar P. et al. - A liquid C. elegans assay for therapeutic phage testing

log-rank test was used to analyze the difference in survival rates in GraphPad Prism 7.0. A statistically significant difference $(p<0.05)$ was observed in the treatment groups. 
Figure 5

A

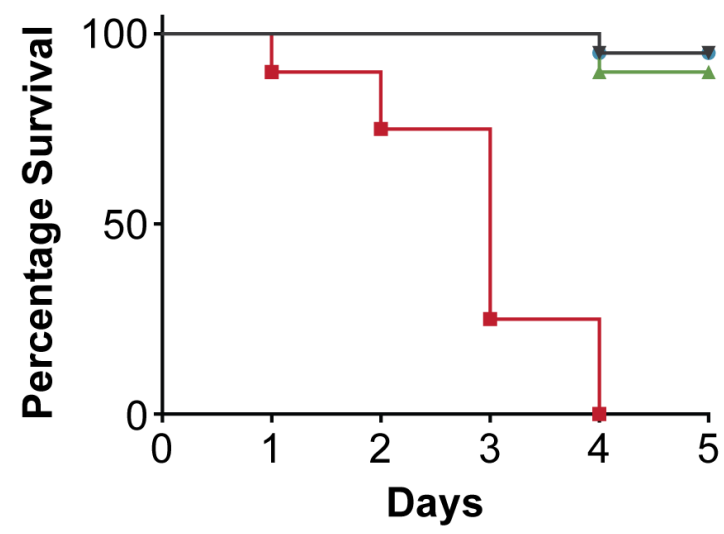

C

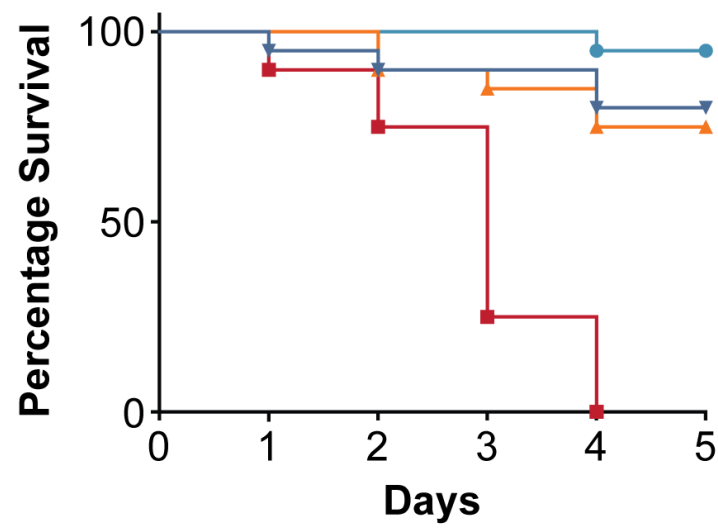

B

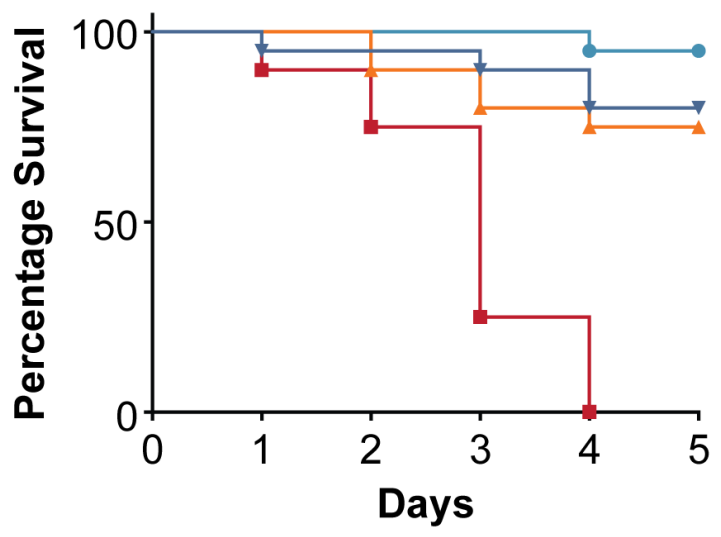

$\mathbf{D}$

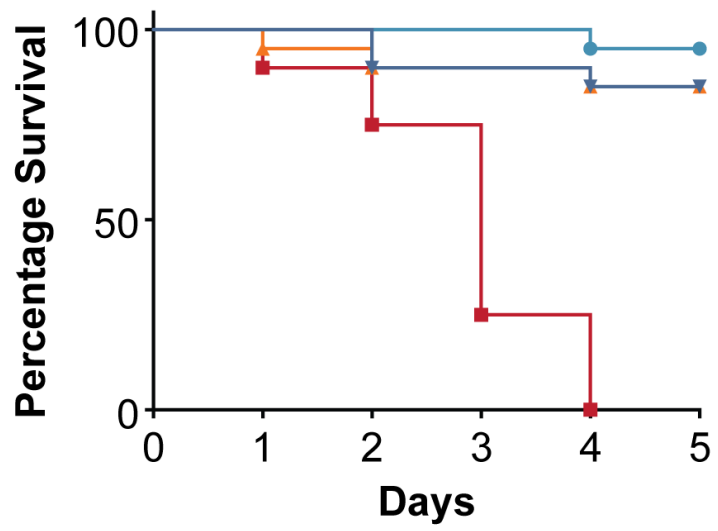

$\rightarrow$ Control $\rightarrow$ Bacteria $\rightarrow$ Phage $\rightarrow$ Heat-inactivated $\rightarrow$ Therapeutic $\rightarrow$ Prophylaxis

Figure 5: Pathogenicity of Enterobacter cloacae strain 140 in C. elegans and efficacy of Enterobacter phage myPSH1140 against E. cloacae infections. The control group consisted of $C$. elegans fed with E. coli OP50 and exposed to E. cloacae strain $140\left(\mathrm{OD}_{600}=0.6\right)$ that kills $C$. elegans in liquid medium. 20 nematodes were used in each group. Representative survival curves of $C$. elegans following infection by $E$. cloacae strain 140 in (A) liquid medium consisting of M9 buffer and E. cloacae culture or Enterobacter phage or heat-inactivated bacteria and $(\mathbf{B}, \mathbf{C}, \mathbf{D})$ survival curves of $C$. elegans following infection with E. cloacae strain 140 and treatment with Enterobacter phage, therapeutic and prophylactic treatment. (B) Survival curves of $C$. elegans infected and treated with bacteria and phage ratio of $1: 1$ i.e. $10^{5} \mathrm{CFU} / \mathrm{mL}$ and $10^{5} \mathrm{PFU} /$ $\mathrm{mL}$, (C) Survival curves of $C$. elegans infected and treated with bacteria and phage ratio of $1: 10$ i.e. $10^{5} \mathrm{CFU} / \mathrm{mL}$ and $10^{6} \mathrm{PFU} / \mathrm{mL}$, (D) Survival curves of C. elegans infected and treated with bacteria and phage ratio of 1:100 i.e. $10^{5} \mathrm{CFU} / \mathrm{mL}$ and $10^{7} \mathrm{PFU} / \mathrm{mL}$. The survival curves were plotted using Kaplan-Meier method and log-rank test was used to 
bioRxiv preprint doi: https://doi.org/10.1101/2022.01.05.474866; this version posted January 5, 2022. The copyright holder for this preprint (which was not certified by peer review) is the author/funder, who has granted bioRxiv a license to display the preprint in perpetuity. It is made available under aCC-BY-NC-ND 4.0 International license.

Manohar P. et al. - A liquid C. elegans assay for therapeutic phage testing

analyze the difference in survival rates in GraphPad Prism 7.0. A statistically significant difference $(p<0.05)$ was observed in the treatment groups. 


\section{Figure 6}

A

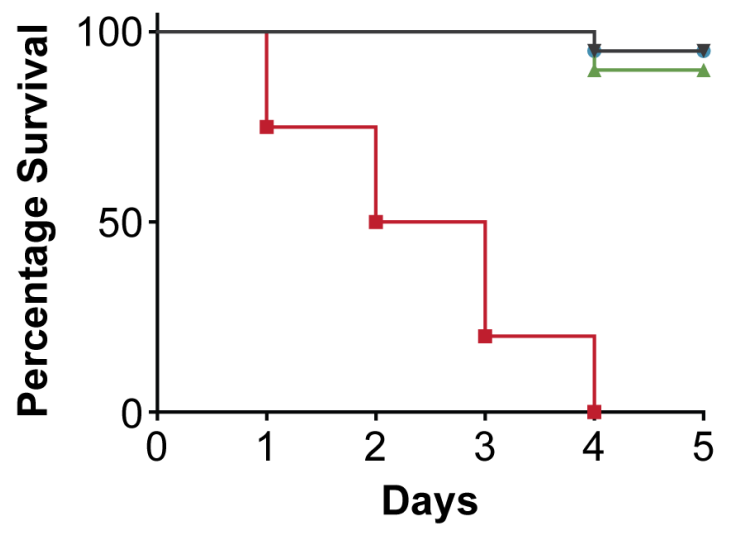

C

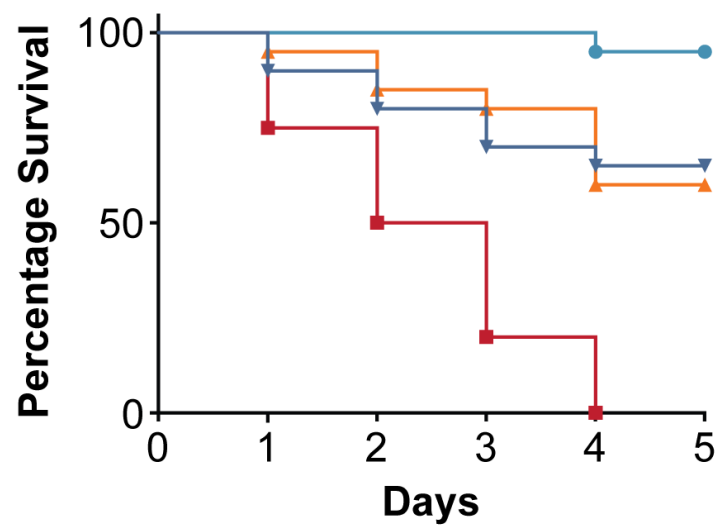

B

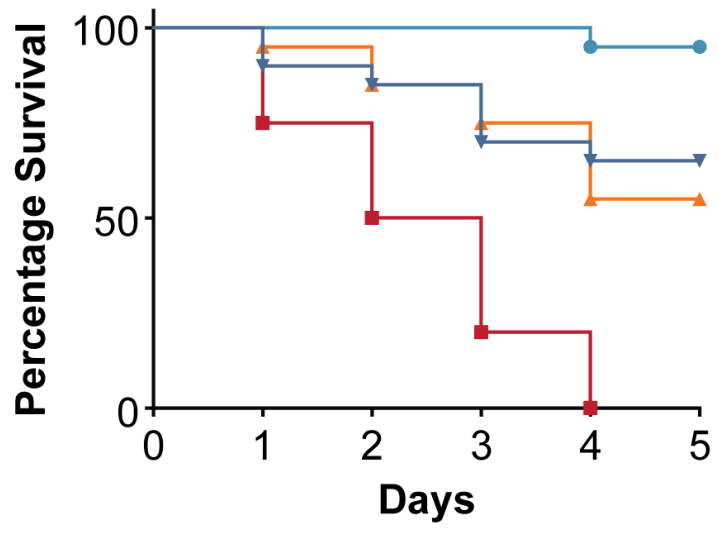

D

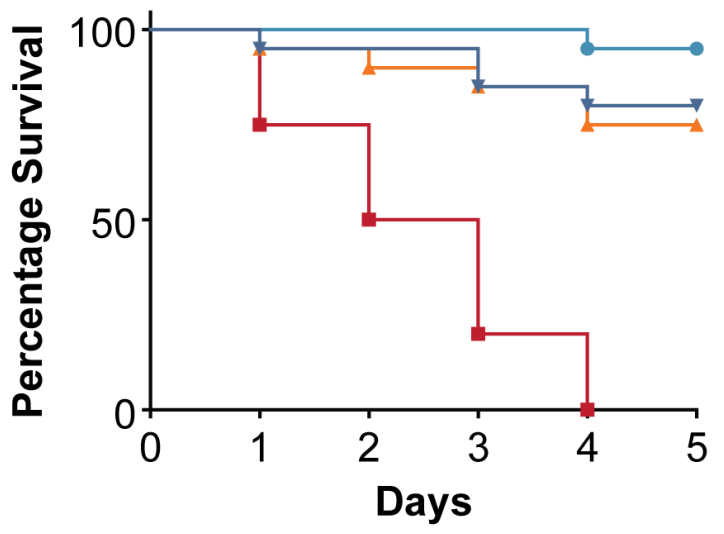

$\rightarrow$ Control $\rightarrow$ Bacteria $\rightarrow$ Phage $\rightarrow$ Heat-inactivated $\rightarrow$ Therapeutic $\rightarrow$ Prophylaxis

Figure 6: Pathogenicity of multi-bacterial culture in C. elegans and efficacy of phage cocktails against poly-microbial infections. The control group consisted of $C$. elegans fed with $E$. coli OP50. 20 nematodes were used in each group. Poly-microbial culture (E. coli 131, E. coli $311, K$. pneumoniae 235, E. cloacae 140) kills C. elegans in liquid medium. Representative survival curves of $C$. elegans following infection by polymicrobial culture in (A) liquid medium consisting of M9 buffer and bacterial culture or phage cocktail or head-inactivated bacteria and $(\mathbf{B}, \mathbf{C}, \mathbf{D})$ survival curves of $C$. elegans following infection with poly-microbial bacteria and treatment with phage cocktail, therapeutic and prophylactic treatment. (B) Survival curves of $C$. elegans infected and treated with poly-microbial bacteria and phage cocktail ratio of 1:1 i.e. $10^{5} \mathrm{CFU} / \mathrm{mL}$ and $10^{5} \mathrm{PFU} / \mathrm{mL}$, (C) Survival curves of $C$. elegans infected and treated with poly-microbial bacteria and phage cocktail ratio of 1:10 i.e. $10^{5} \mathrm{CFU} / \mathrm{mL}$ and $10^{6} \mathrm{PFU} / \mathrm{mL}$, (D) Survival curves of $C$. elegans infected and treated with poly-microbial bacteria and phage cocktail ratio of 1:100 i.e. $10^{5} \mathrm{CFU} / \mathrm{mL}$ and $10^{7} \mathrm{PFU} / \mathrm{mL}$. Survival curves were plotted using Kaplan-Meier method and log-rank test was used to analyze the difference in 
bioRxiv preprint doi: https://doi.org/10.1101/2022.01.05.474866; this version posted January 5, 2022. The copyright holder for this preprint

(which was not certified by peer review) is the author/funder, who has granted bioRxiv a license to display the preprint in perpetuity. It is made available under aCC-BY-NC-ND 4.0 International license.

Manohar P. et al. - A liquid C. elegans assay for therapeutic phage testing

survival rates in GraphPad Prism 7.0. A statistically significant difference $(p<0.05)$ was observed in the treatment groups. 


\section{Figure 7}

A

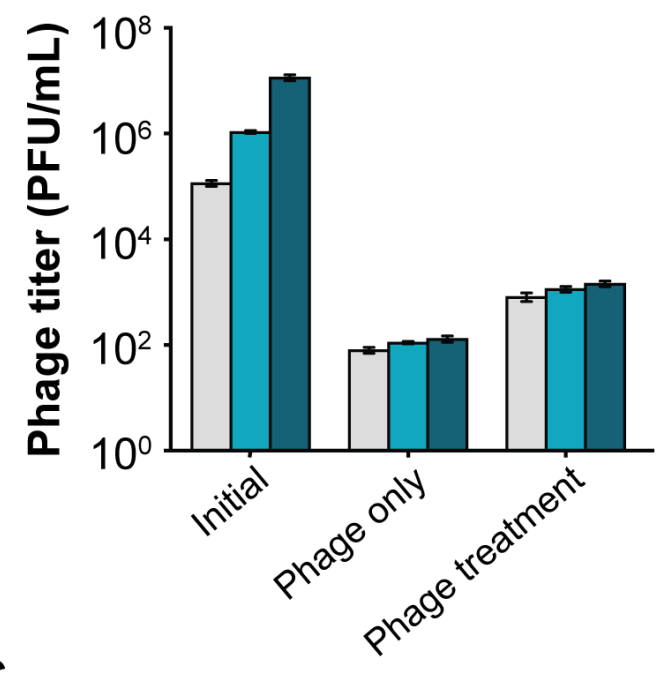

C

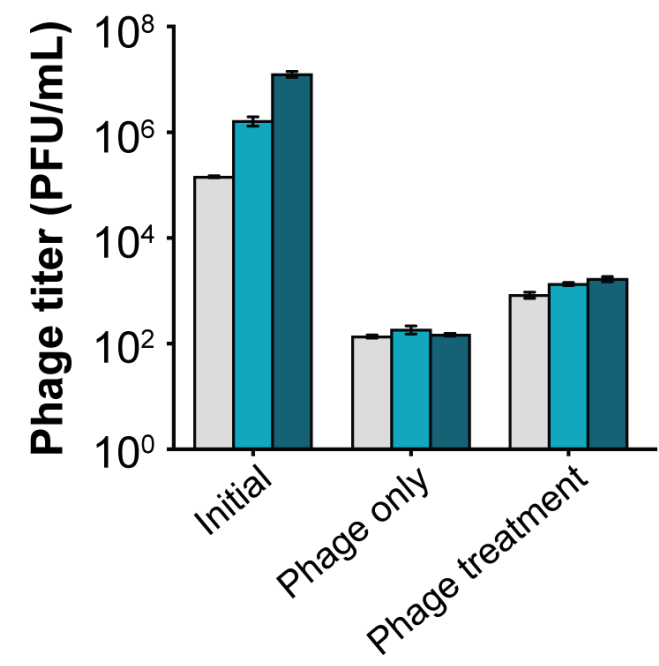

B
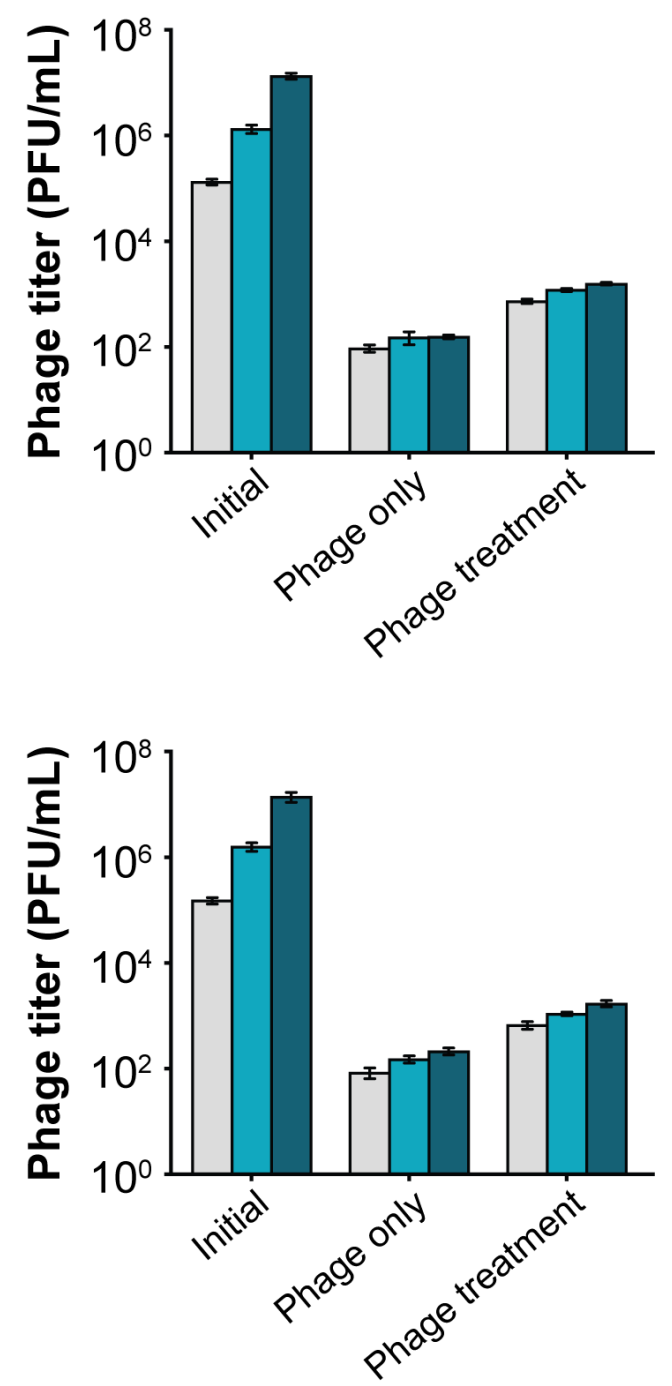

\section{$10^{5} \mathrm{PFU} / \mathrm{mL} \quad \square 10^{6} \mathrm{PFU} / \mathrm{mL}$}

$10^{7} \mathrm{PFU} / \mathrm{mL}$

Figure 7: Bacteriophage enumeration from $C$. elegans after 4 days of exposure under two different conditions, (1) Phage only i.e. C. elegans was introduced to phage alone, and (2) Phage treatment i.e. C. elegans infected with bacteria was treated with phages. (A) Escherichia phage myPSH1131, (B) Escherichia phage myPSH2311, (C) Klebsiella phage myPSH1235 and (D) Enterobacter phage myPSH1140. After 4 days of treating $C$. elegans with phages, the nematodes were washed, grained and titrated for the presence of phages. The number of phages in treatment group was 10 times higher than the untreated group. The error bars represent the standard mean of three independent experiments. 


\section{Figure 8}

\begin{tabular}{rccccccccc} 
& CN1 & CN2 & CN3 & PC & NC & HC & T1 & T2 \\
\cline { 2 - 10 } M9 buffer & $60 \%$ & $100 \%$ & $60 \%$ & $60 \%$ & $60 \%$ & $60 \%$ & $40 \%$ & $40 \%$ \\
C. elegans & 20 & 20 & 20 & 20 & 20 & 20 & 20 & 20 \\
Bactive or inactivated) & $40 \%$ & - & $40 \% *$ & $40 \%$ & - & $40 \%$ & $30 \%$ & $30 \%$ \\
Bacteriophage & - & - & - & - & $40 \%$ & - & $30 \%$ & $30 \%$ \\
\hline
\end{tabular}

Figure 8: Representation of the study groups used to evaluate the efficacy of bacteriophages in treating bacterial infections in C. elegans model. In a 96 well microtiter plate, experiments were conducted in triplicate. Details are as follows: Negative controls CN1 - M9 buffer (60\%), E. coli OP50 (40\%) and 20 nematodes; CN2 M9 buffer and 20 nematodes; CN3 - M9 buffer (60\%), TSB (40\%) and 20 nematodes. PC (infection control) - M9 buffer (60\%), overnight bacterial culture of $E$. coli or $K$. pneumoniae or E. cloacae (40\%) and 20 nematodes. NC (phage control) - M9 buffer (60\%), bacteriophage (Escherichia phage myPSH1131, Escherichia phage myPSH2311, Klebsiella phage myPSH1235 and Enterobacter phage myPSH1140) 
(40\%) and 20 nematodes. HC (heat-inactivated bacteria control) - M9 buffer (60\%), heat-killed bacterial culture of E. coli or K. pneumoniae or E. cloacae $(40 \%)$ and 20 nematodes. T1 (treatment group, phages were added 2 hrs after bacterial infection) M9 buffer (40\%), overnight bacterial culture of E. coli or K. pneumoniae or E. cloacae (30\%), bacteriophage (30\%) and 20 nematodes. T2 (prophylactic treatment group, phages were added $1 \mathrm{hr}$ before the bacterial infection) - M9 buffer (40\%), bacteriophage (30\%), overnight bacterial culture of E. coli or K. pneumoniae or E. cloacae (30\%) and 20 nematodes. * indicates TSB was used instead of bacteria. 


\section{Supplementary figures:}

\section{Supplementary Figure 1}

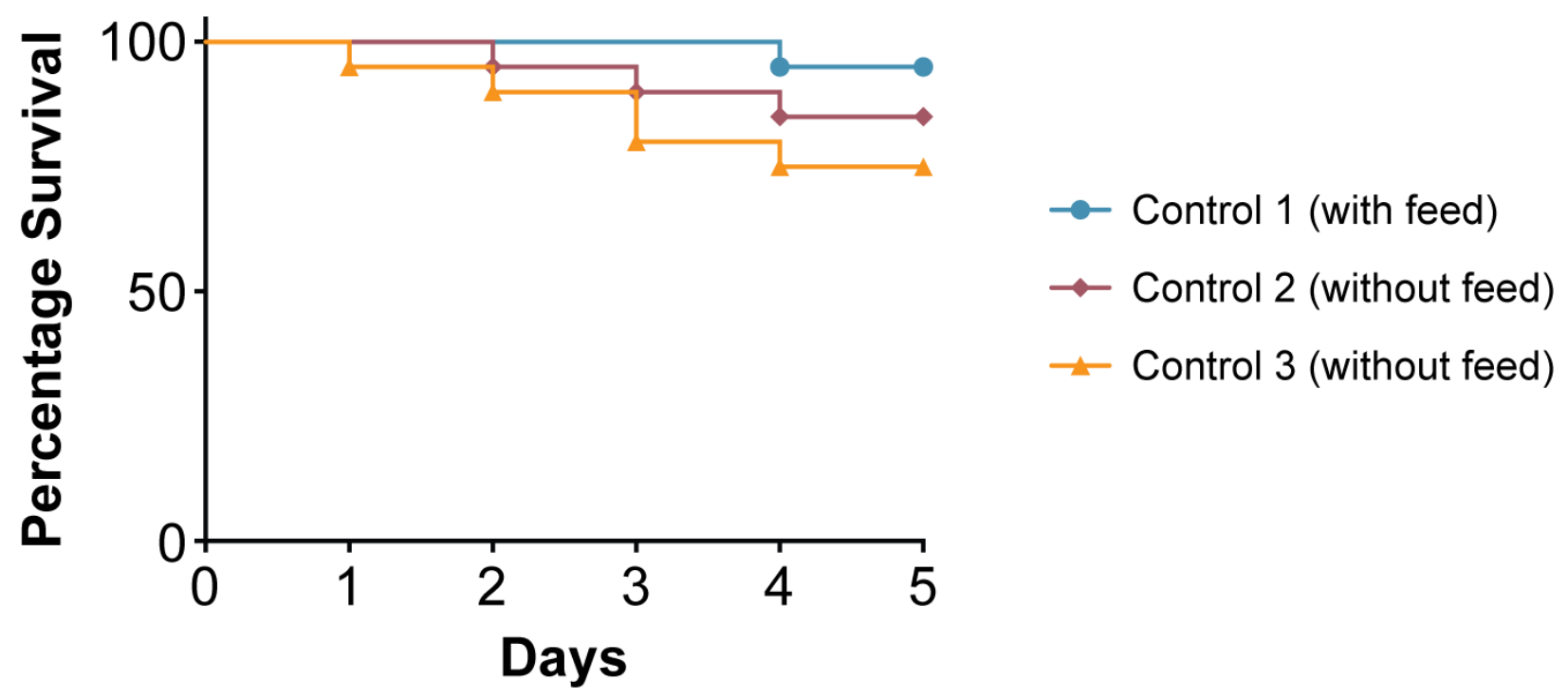

S. figure 1: Survival curves of nematodes (C. elegans). Nematodes were kept in varying growth conditions; Control 1: nematodes were fed with E. coli OP50, Control 2 (liquid media) \& Control 3 (solid-media): nematodes were not fed. Survival curves were plotted using Kaplan-Meier method and log-rank test was used to analyze the difference in survival rates in GraphPad Prism 7.0. 


\section{Supplementary Figure 2}

A

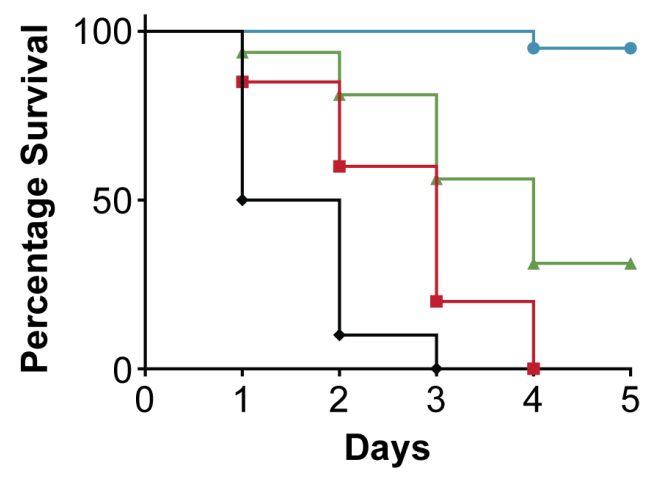

C

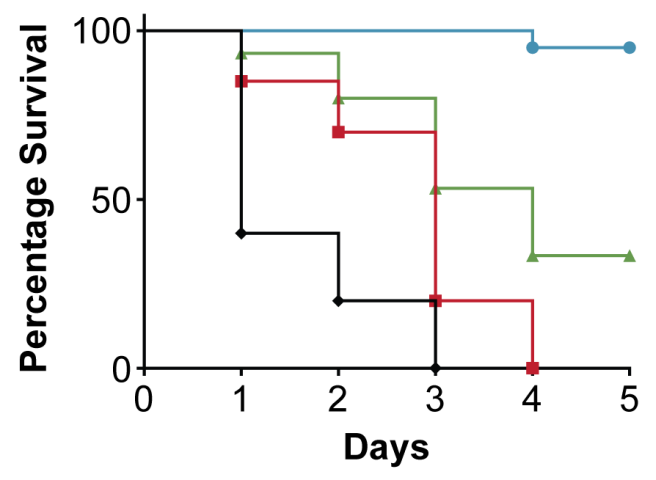

E

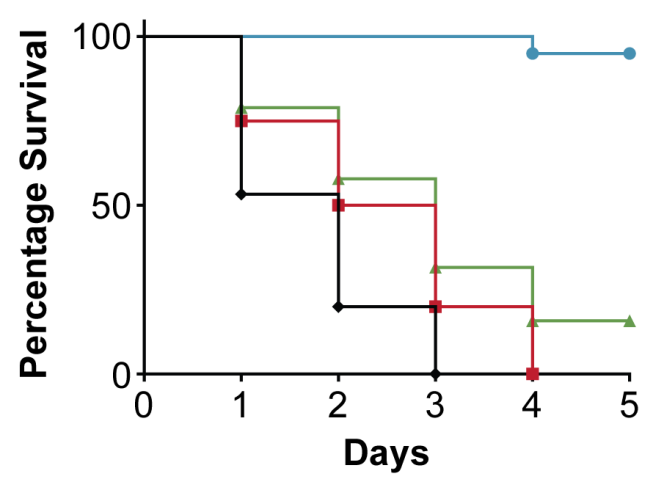

B

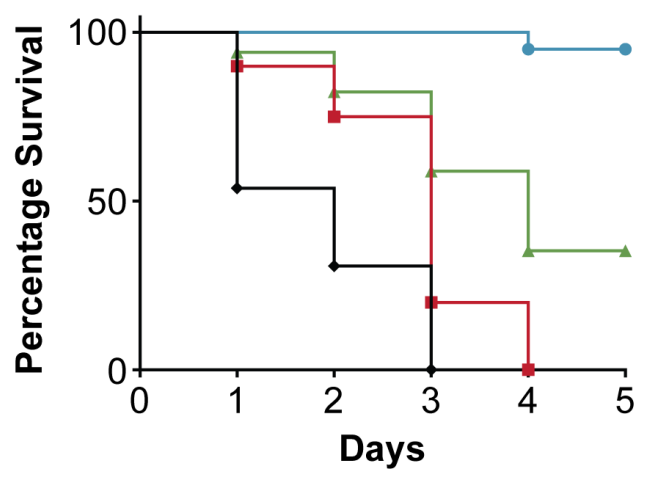

D

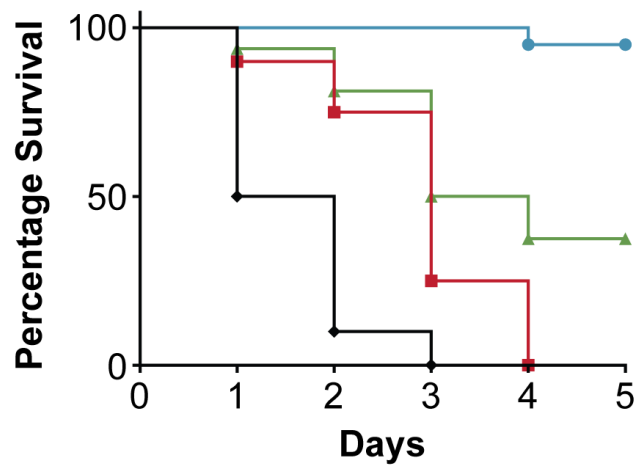

- Control

- Bacteria $\left(10^{3} \mathrm{CFU} / \mathrm{mL}\right)$

- Bacteria $\left(10^{5} \mathrm{CFU} / \mathrm{mL}\right)$

- Bacteria $\left(10^{7} \mathrm{CFU} / \mathrm{mL}\right)$

S. figure 2: Survival curves of nematodes (C. elegans) when infected with pathogenic bacteria at different concentrations, $10^{3}, 10^{5}$ and $10^{7} \mathrm{CFU} / \mathrm{mL}$. (A) $C$. elegans infected with Escherichia coli 131; (B) C. elegans infected with Escherichia coli 311; (C) C. elegans infected with Klebsiella pneumoniae 235; (D) C. elegans infected with Enterobacter cloacae 140. The survival curves were plotted using Kaplan-Meier method in GraphPad Prism 7.0. 


\section{Supplementary Figure 3}

A

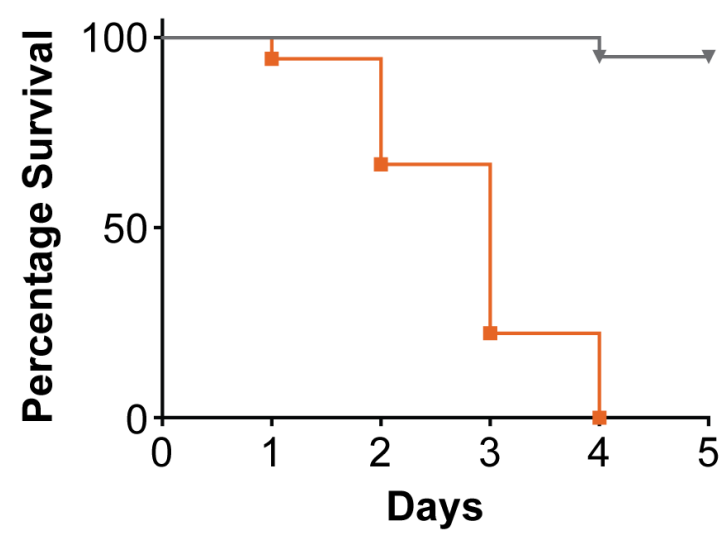

C

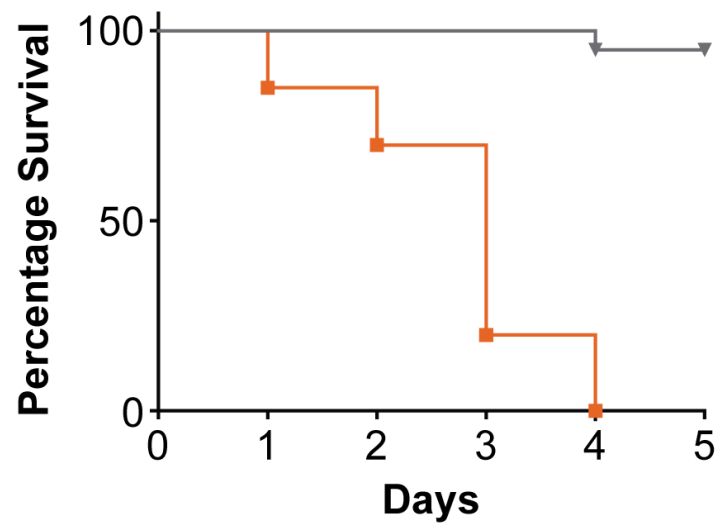

$\rightarrow-$ Bacteria
B

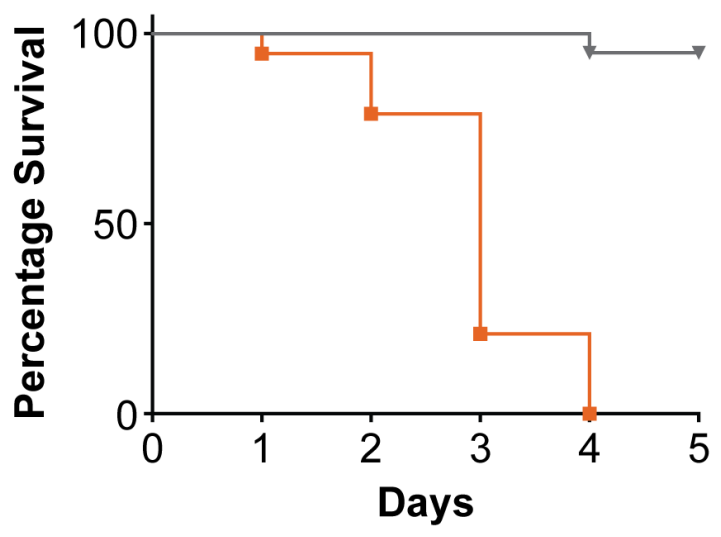

D

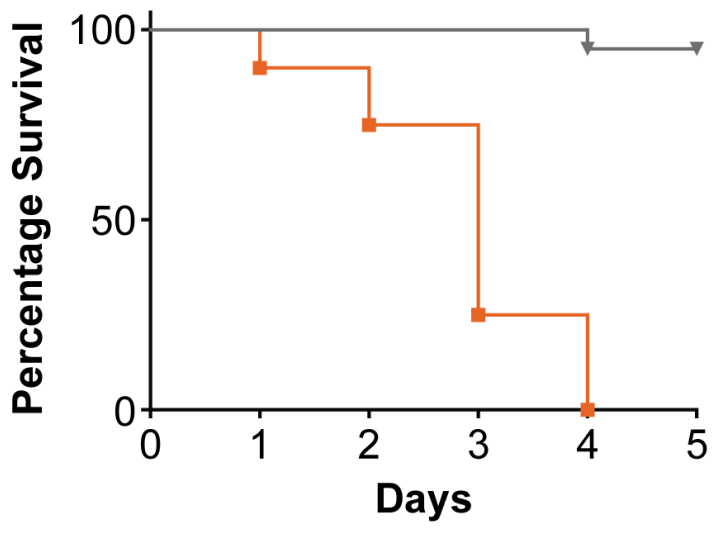

S. figure 3: Survival curves of nematodes (C. elegans) when infected with live bacteria and heat-killed bacteria. (A) C. elegans infected with Escherichia coli 131; (B) C. elegans infected with Escherichia coli 311; (C) C. elegans infected with Klebsiella pneumoniae 235; (D) C. elegans infected with Enterobacter cloacae 140. The survival curves were plotted using Kaplan-Meier method in GraphPad Prism 7.0. 